\title{
Dead Burial Ceremony: An Anthropological Study
}

\section{Nadia Wali Jabbar ${ }^{1}$}

Received: Feb 23, 2018

\author{
Hardi Zead Salih ${ }^{2}$
}

Reviewed: Mar 11, 2018
Accepted: Mar 17, 2018

\begin{abstract}

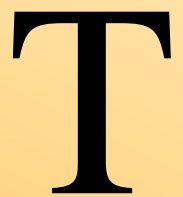

his is an anthropological study; the study tries to show the tradition of death burial ceremony in Erbil city. The purpose of the study: the trial of describing and showing death burial ceremony according to Erbil's traditions and culture; to know how much effects does it have on the way people act and the changes that have happened to this ceremony and showing them; mentioning the functions of this ceremony. In this study ethnographical and comparative methods are used. Purposive sample is also used the type is (intensive sample) which contains 8 individuals the used tool in this study (interview and observation). The aim of the study: this ceremony keeps the way deaths are buried. This ceremony shows the death's social status; at the same time, the ceremony strengthens the social relations, till now this ceremony has not lost its respect. There have been some changes on the ceremony traditions and new traditions have been added as bringing women for reading holy Quraan and (mawlood) for money; according to that Erbil is a multicultural city. Exaggerations have been there because of Improvement of Erbil's economy. Salat isqat are done anymore because humans don't need this after they die. Death burial ceremony has functions like: cultural, social, regional and psychological.
\end{abstract}

Keywords: Dead Burial, Tradition, Death, Culture, Social Status

\section{Recommended citation:}

Jabbar N. W. \& Salih H. Z. (2018). Dead burial ceremony: An anthropological study. International Journal of Kurdish Studies 4 (2), 365-385. doi: 10.21600/ ijoks.454460

\footnotetext{
${ }^{1} \mathrm{PhD}$ Student, Salahaddin University, College of Arts, Sociology Department, Erbil. E-mail: nadia.w.jabbar@gmail.com

${ }^{2}$ Lecturer, Koya University, Faculty of Education, Department of History, Koya. E-mail:hardizead@gmail.com
} 
ملخص بالغة العربية

هذه در اسة انثروبولوجية تسعى لعرض العادات و تقاليد مراسم الدفن في مدينة اربيل. اهداف هذا البحث : محاولة

تحديد دلالات و طقوس الجنائز حسب العادات و تقاليد سكان مدينة اربيل، وذا لى لكي نعرف و يتبين لنا الى ابي مدى اثرت هذه التقاليد على مسيرة تصرف الانس و الافر اد المقيمين في مدينة اربيل. ايضا تحديد التغيرات التي طر ات عليها؛ ظهور اساليب جديدة وعادات جديدة متعلقة بالجنائزو من ثم عرض الوظائف التي تقوم بها هذه المر اسم ـ المنهج المستخدم في الدر اسة هما(المنهج إثثو غر افي و المنهج المقارن) و استخدمة العينة القصدية فيها من نوع (عينة الحالات الغنية). وحدة العينه مكون من (^)فردا من مدينة اربيل اساليب جمع البيانات المستخدمة هي (المقابلة، الملاحظة والملاحظة بالمشاركة).

توصل هذا البحث الى عدة نثلثُج منها: ان هذه المر اسم حافظت على تقاليد دفن اليت. هذه المر اسم تضهر المكانة الاجتماعية للمتوفي، و في نفس الوقت تقوي العلاقات الجنماعية و تعزز ها بين الافر اد حتى الان حافظت هذه المر اسم على تقدير هاو رصانتها بالر غم من ان بعض عاداتها تغيرت و ظهرت تقاليد جديد ة مثل : احضار قارئات القران و قراءة المولد مقابل اجر معين. بقيت تقاليد هذه المر اسم على حالها لدى الطبقة الفقبرة و المتوسطة و لكن يبالغ الطبقة الغنية في التكاليف المادية. مايتعلق بصلات الاسقاط، فللان لا يتم اقامة و اداء هذه العادة بشكل كبير و ذلك بسبب ارتفاع مستوى الوعي الديني، فاصبح الناس يدركون ان الميت لا يحتاج اليها . كما ان هذه المر اسم لها وظائف (ثقافية، الاجتماعية، دينيةو وهاء نفسية).

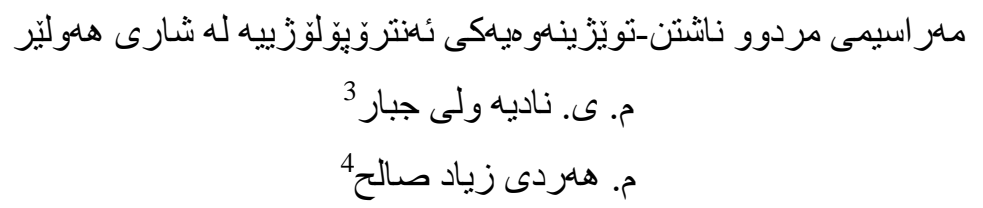

يُوخته

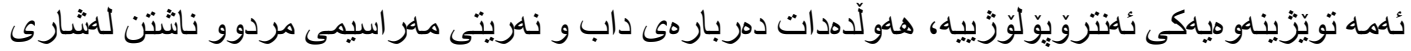

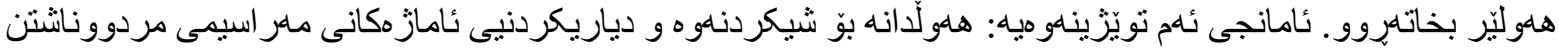

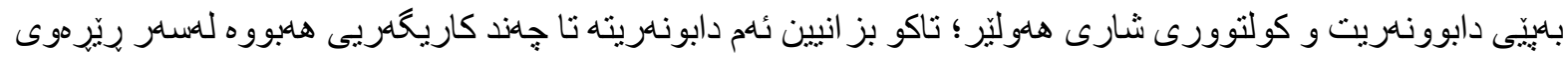

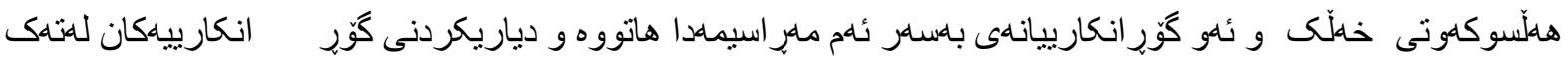

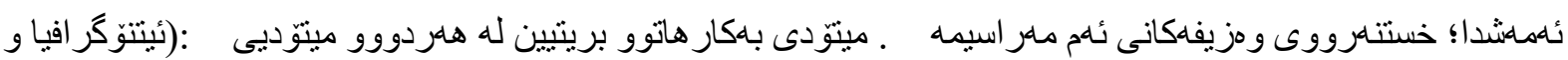

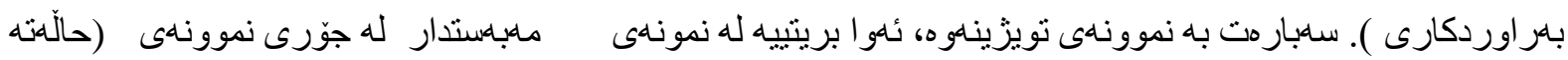

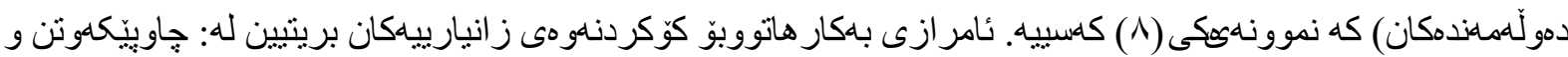
تنيبينى بابهانشدارى.

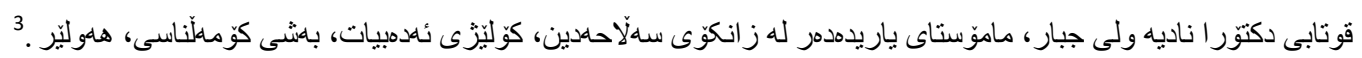

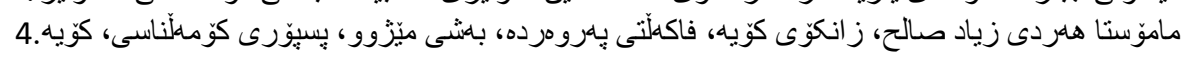




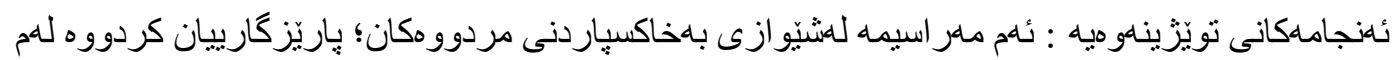

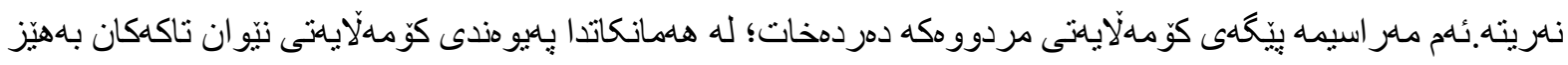

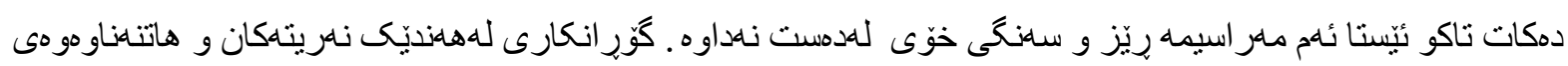

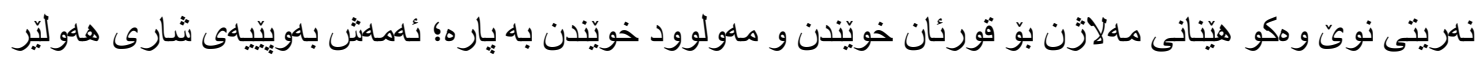

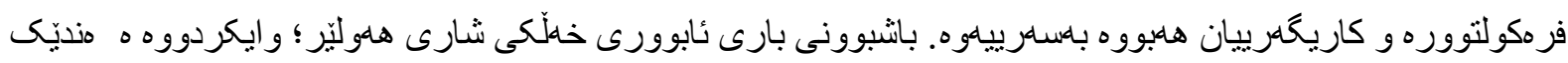

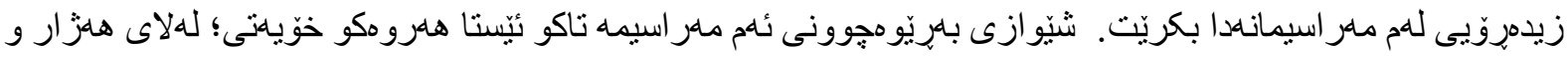

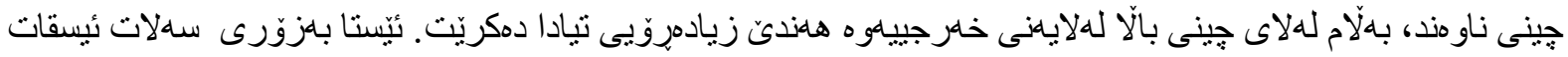

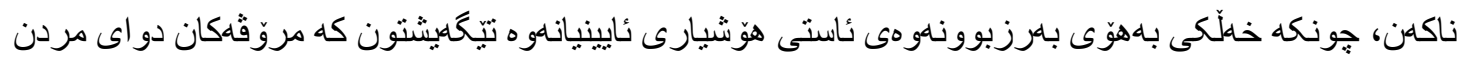

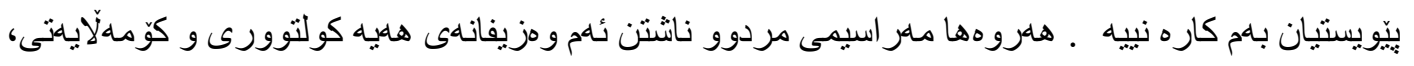
نئيينى و دمروونى.

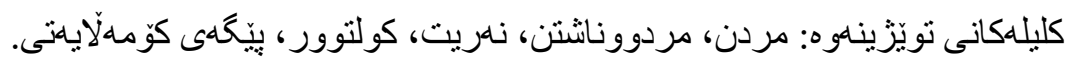

\section{بِّشناكى}

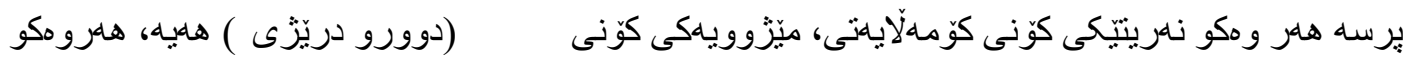

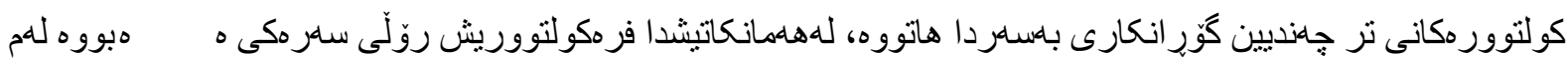

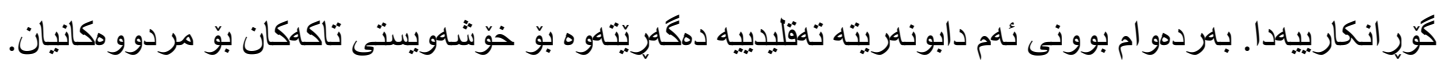

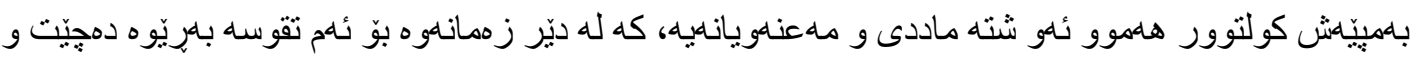

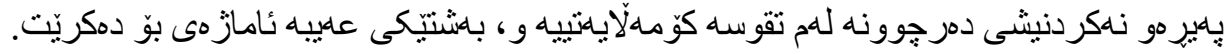

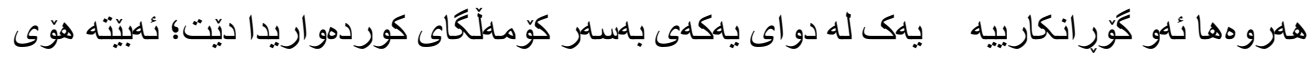

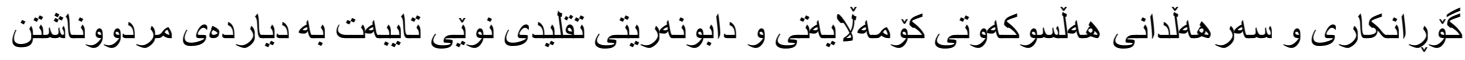

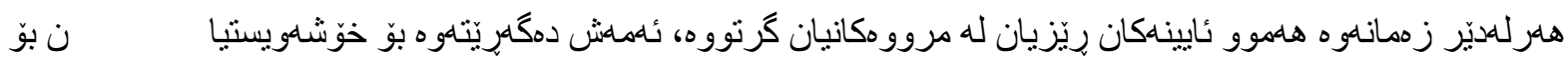

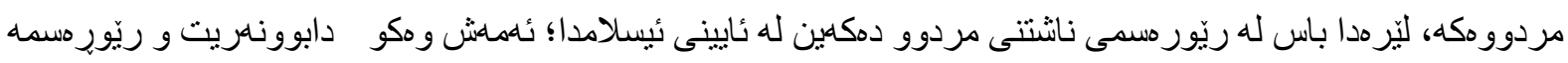

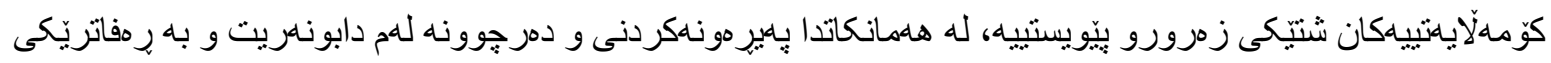

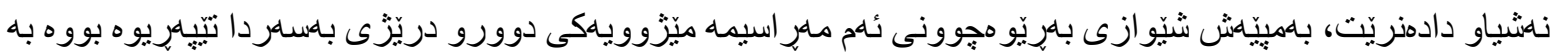

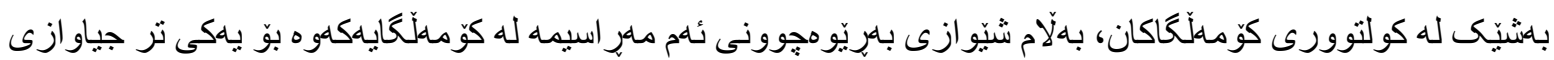
هلين.

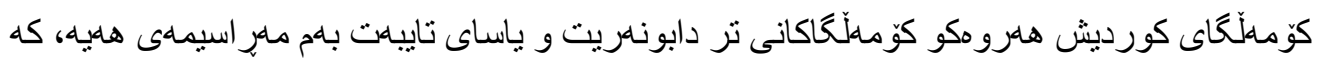

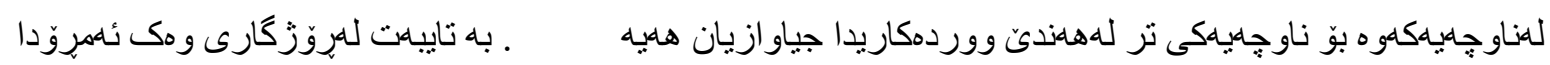

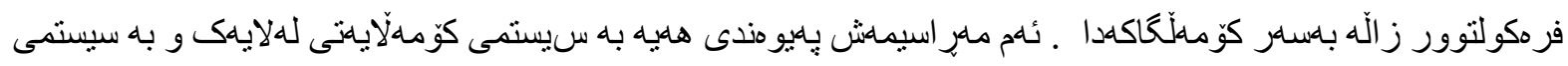

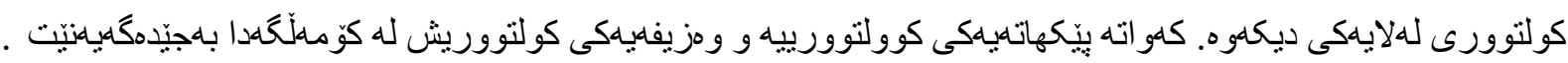

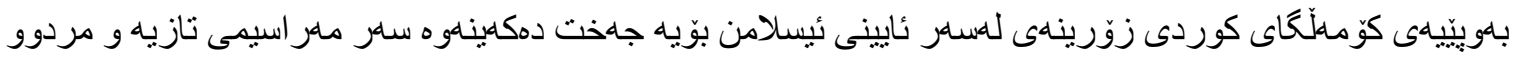
ناثتن لهلاى مسولْمانان. 


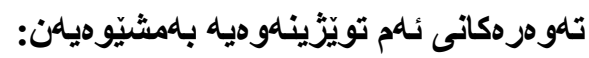
يهكهم: بابهنتى تويَزِينينهوه

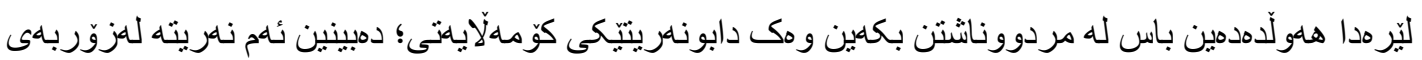

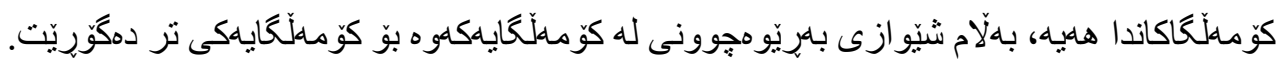

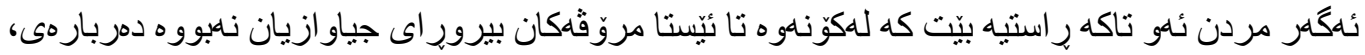

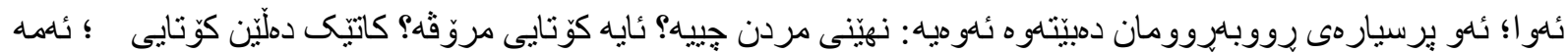

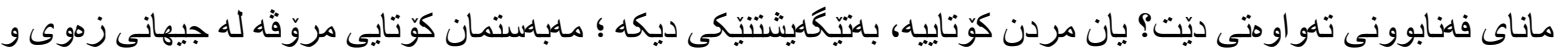

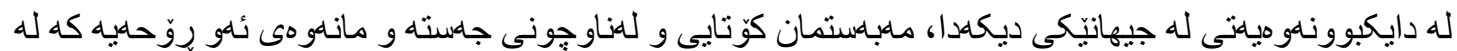

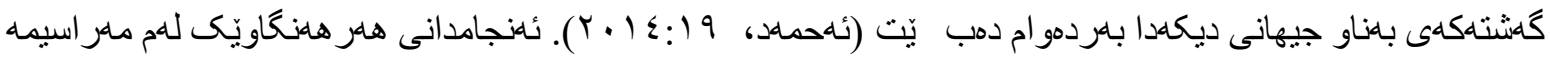

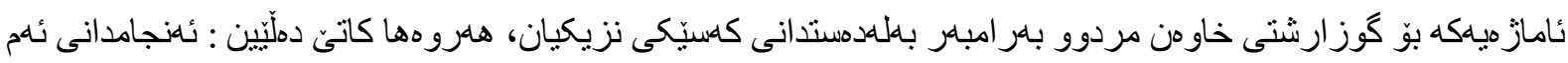

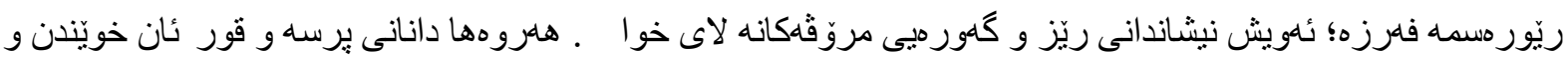

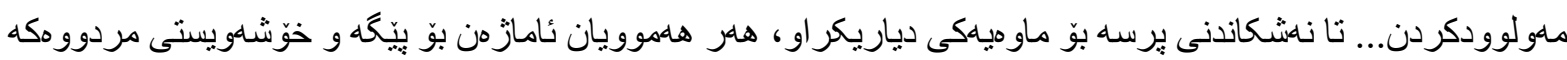
لاى خانهو ادهكهى.

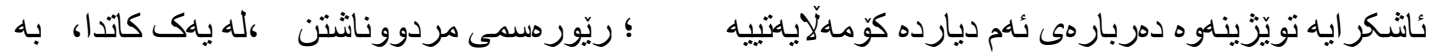

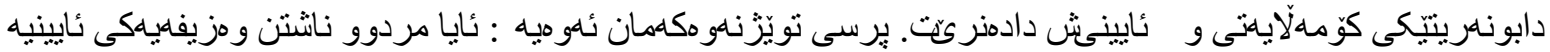

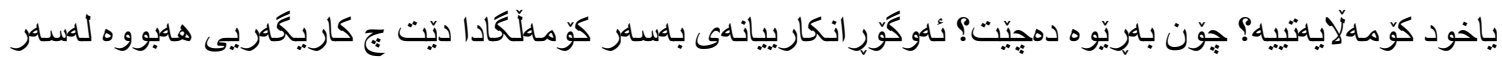

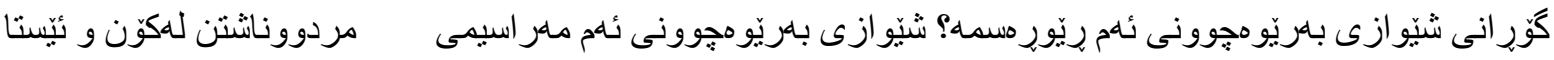
جياو ازى هليه؟

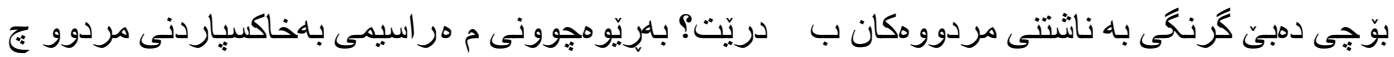

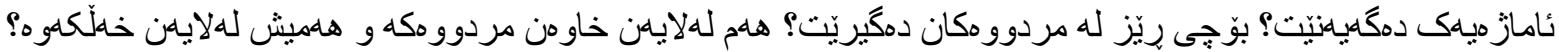
دووهم: كرنحَى تويَزْينهوه

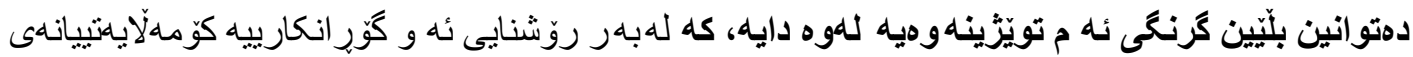

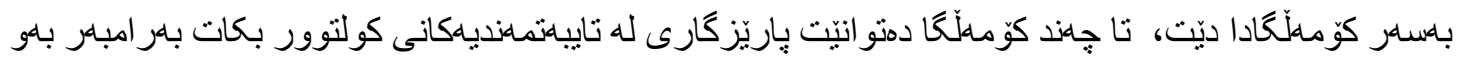

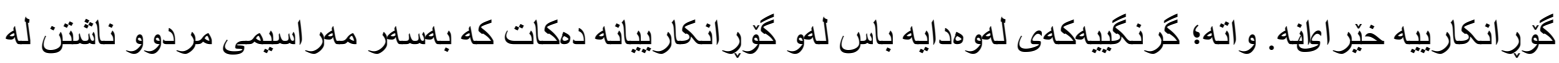
شارى هلوليّردا هاتوون.

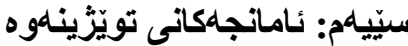

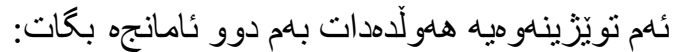

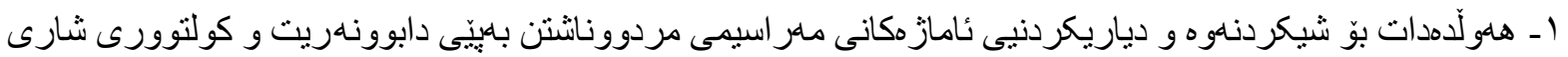

هلهو لِّر.

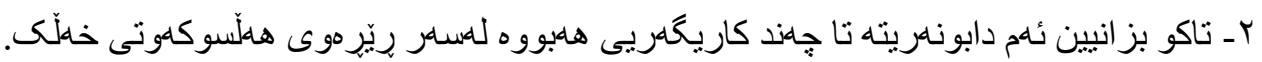
ب_ دهستتيشانكردنى ئهو كوّر انكارييانهى بهسهر ئهم مهر اسيمهدا هاتووه و دياريكردنى كوّر انكارييهكان. 
1

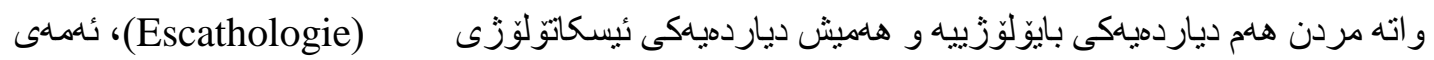

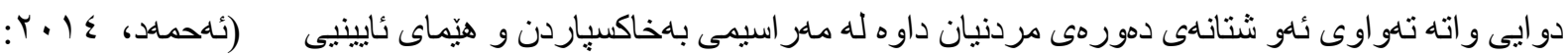

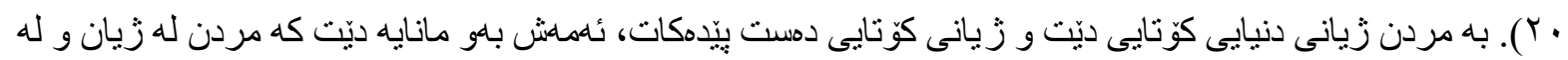

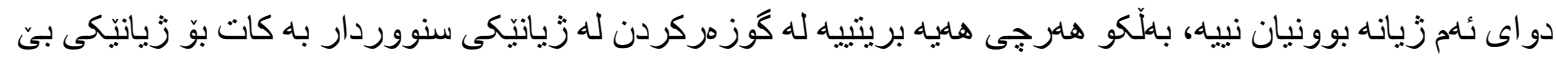

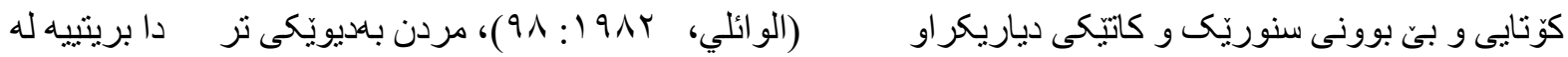

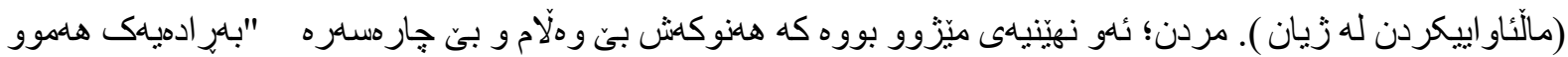

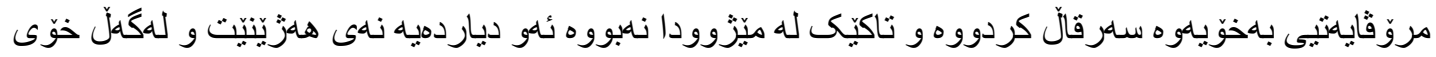

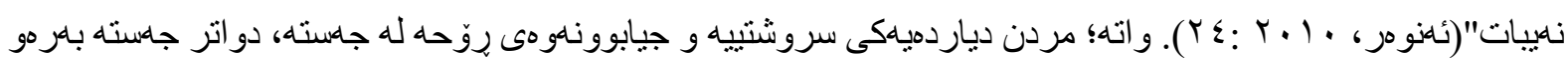

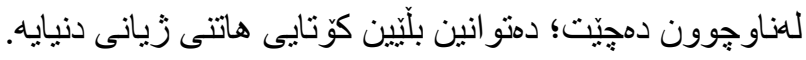

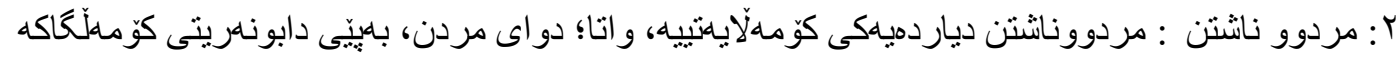

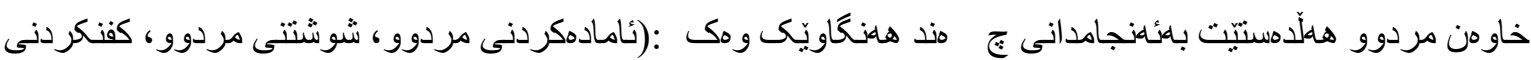

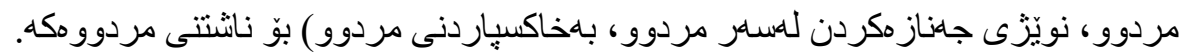

$$
\text { r- ناريت: (Tradition) }
$$

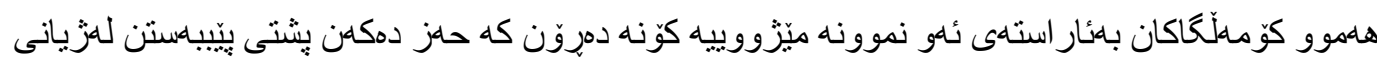

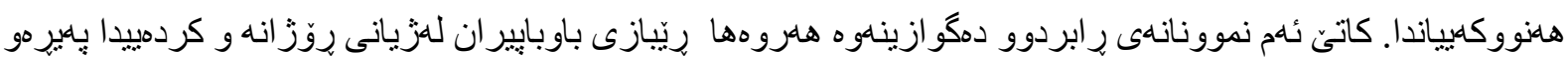

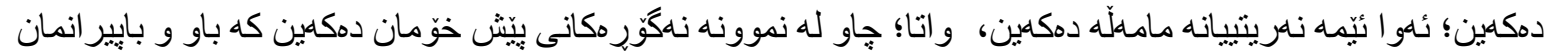

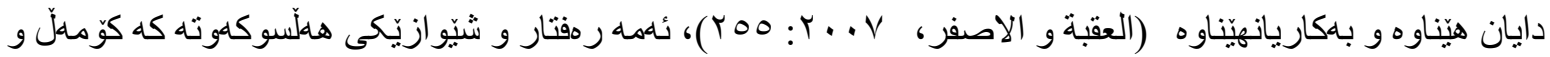

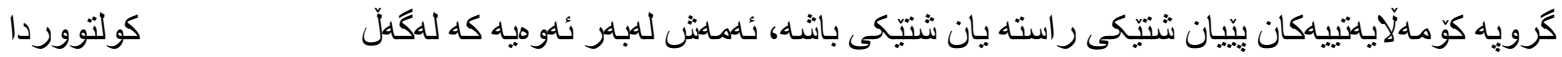

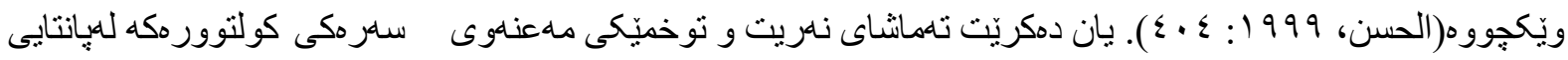

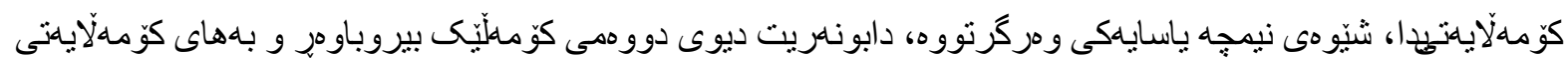

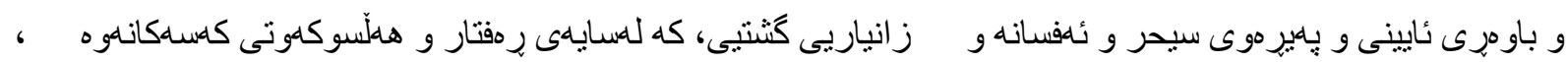

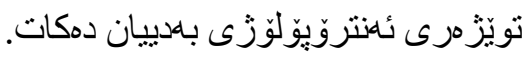

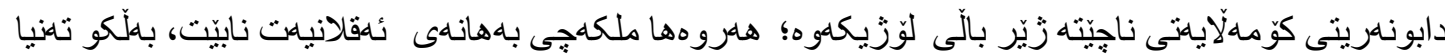

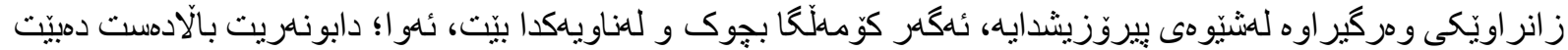

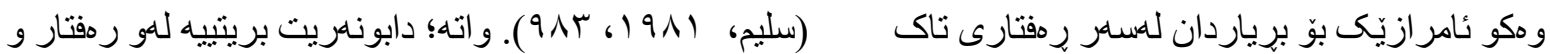

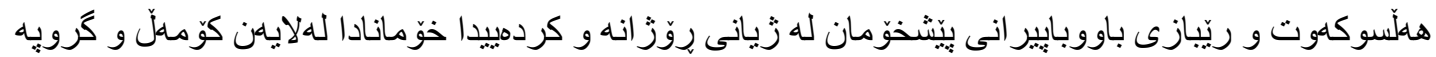

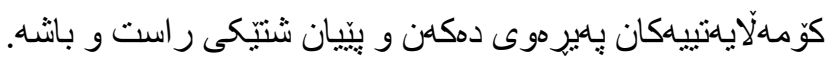

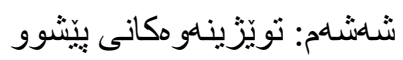

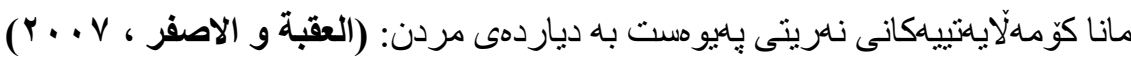

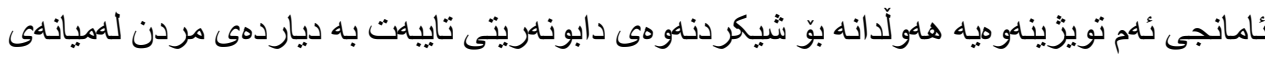

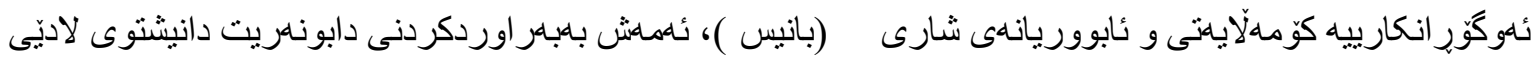


بمدانيشتو انى شار.

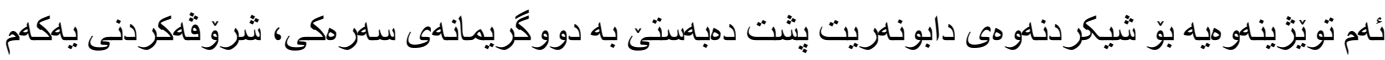

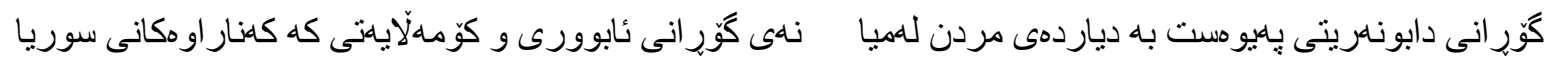

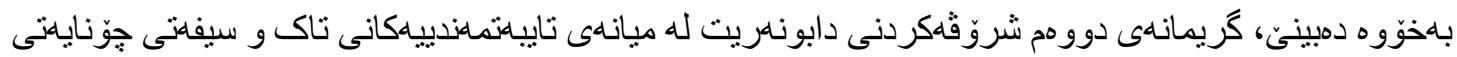

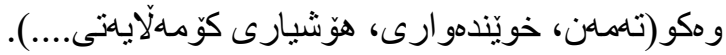

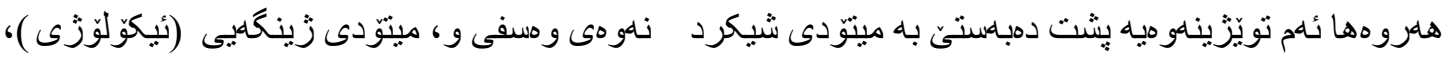

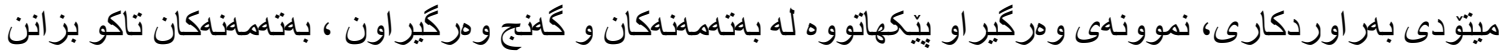

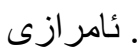

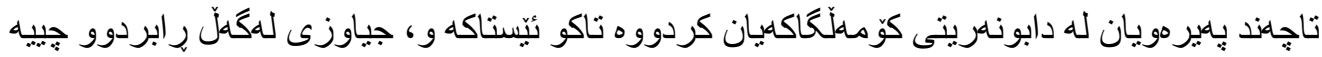

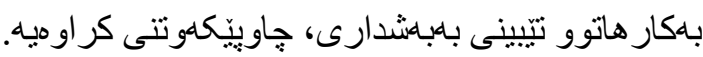

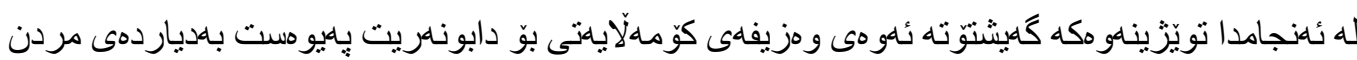

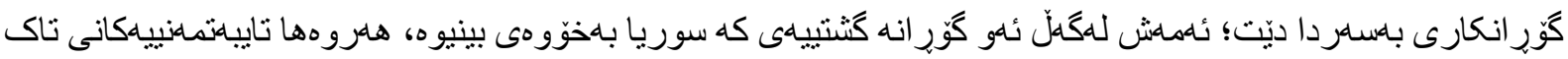

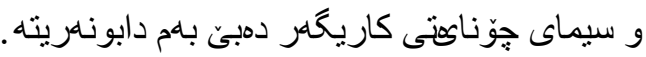

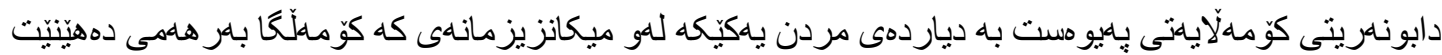

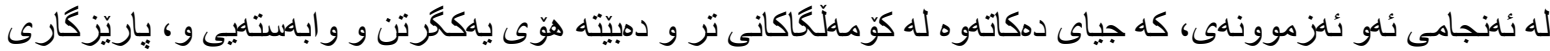

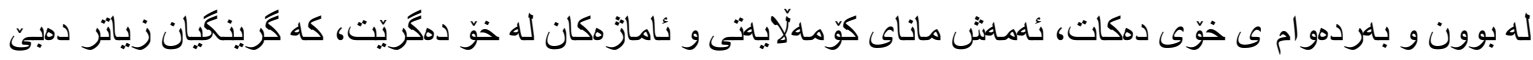

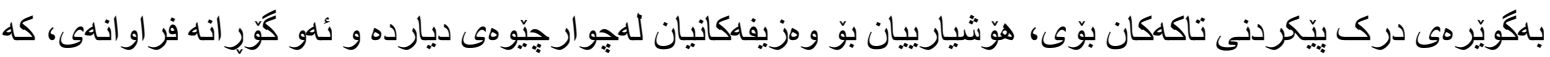

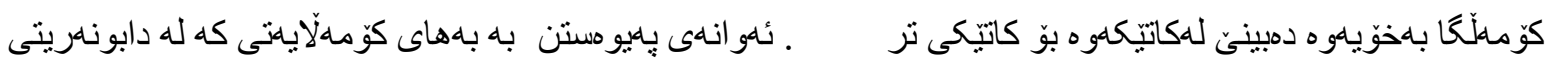

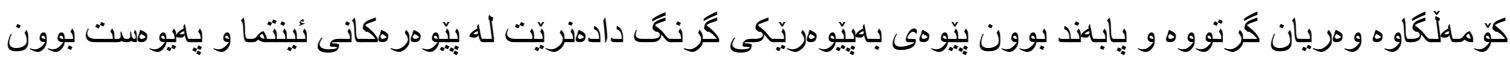

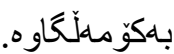

حهوتهم: ميتوّدى تويَزْينهوه

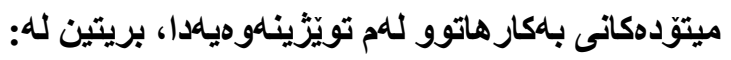

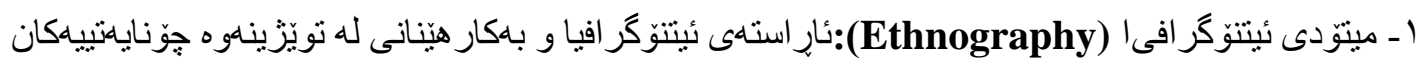

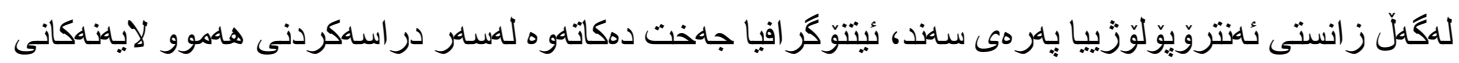

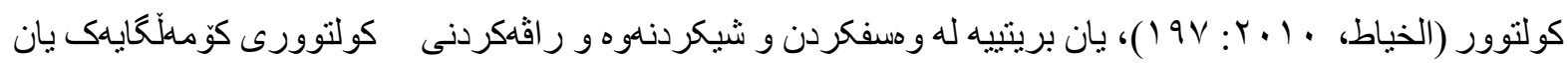

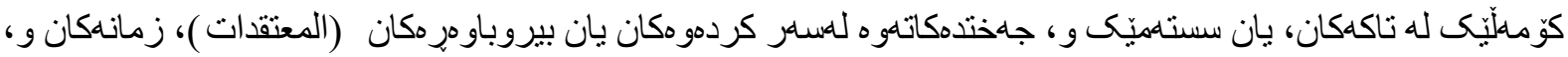

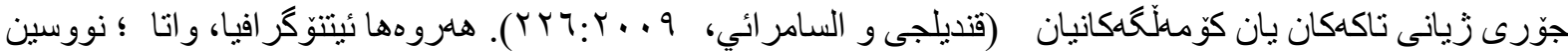

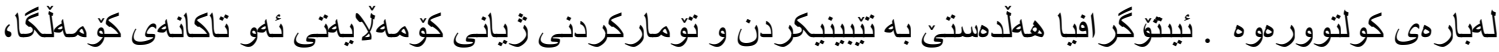

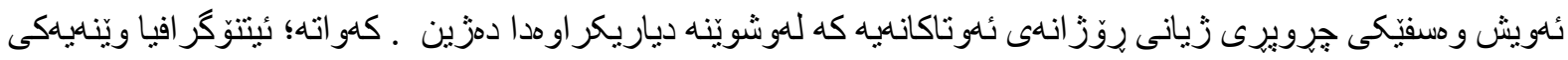

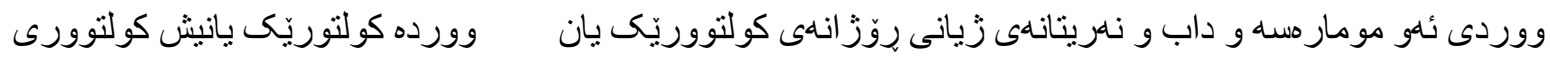

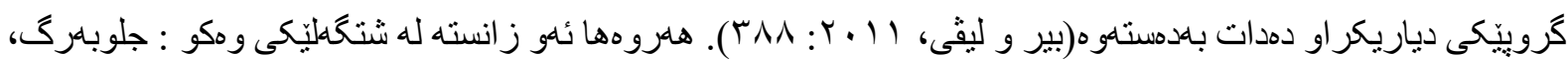

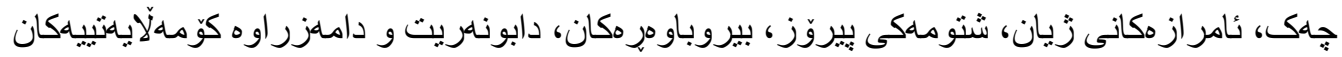

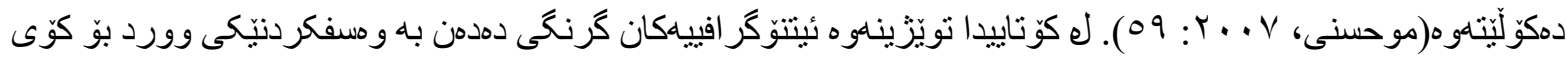

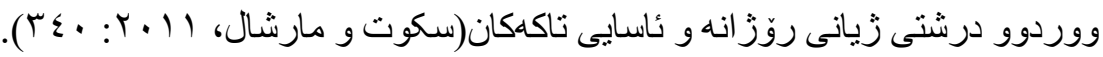




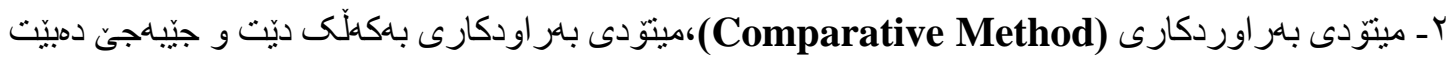

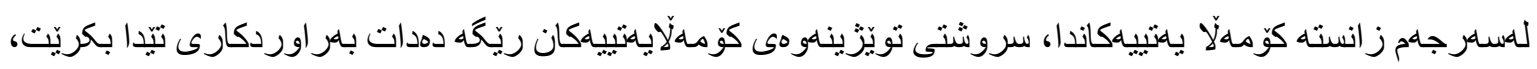

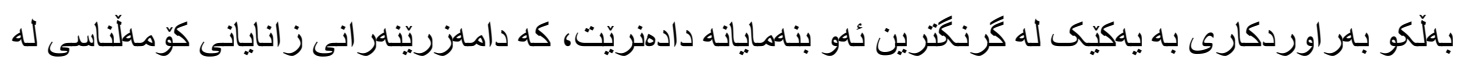

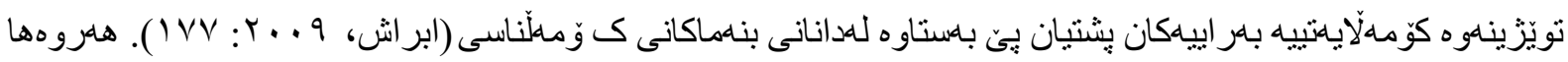

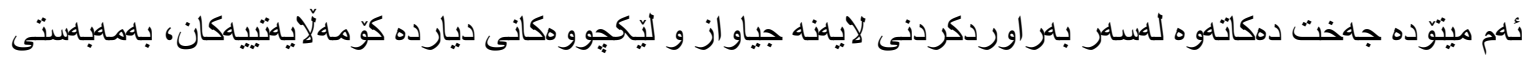

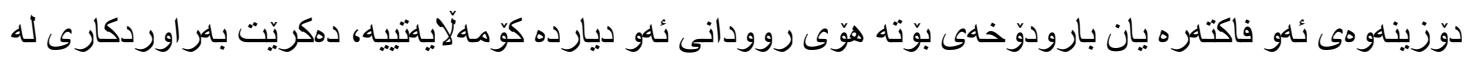

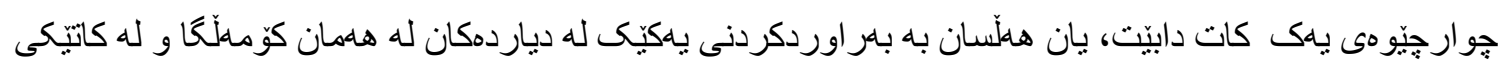

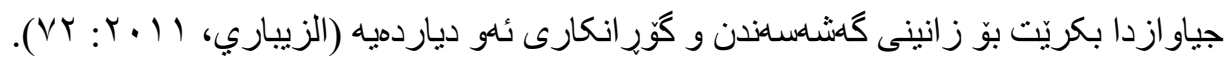

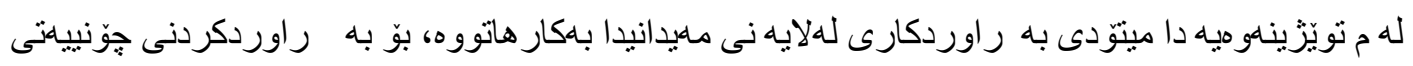

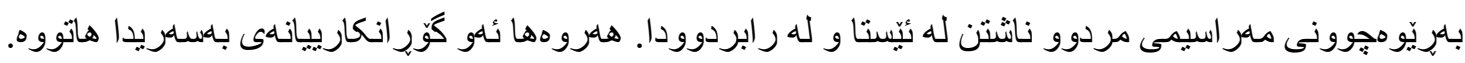

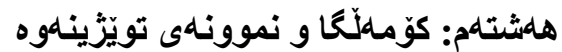

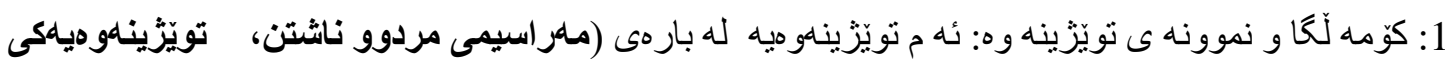

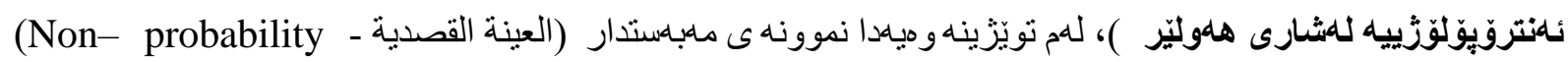

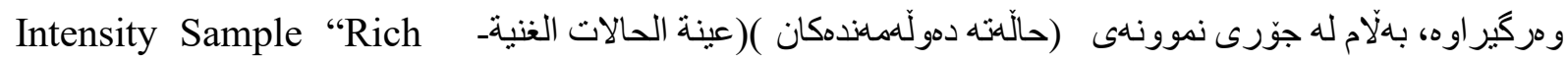

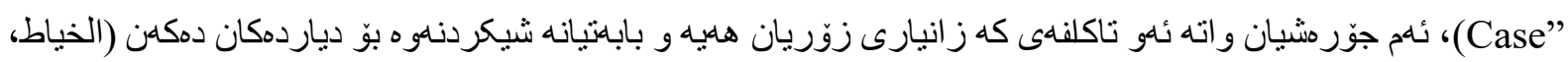

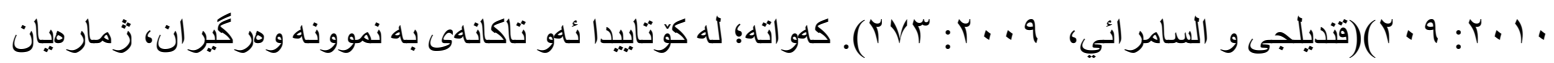

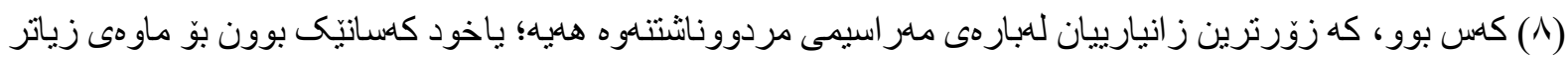

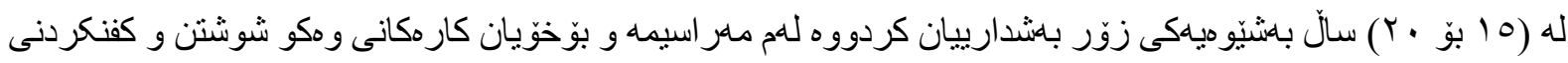

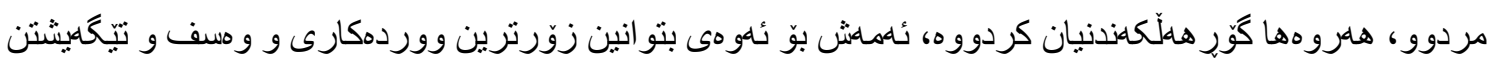

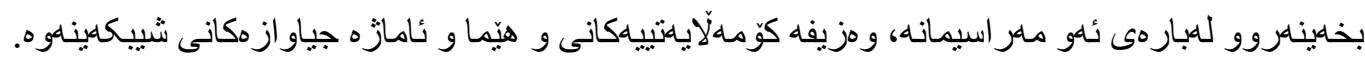
نوّيهم: ئامرازى كوّكردنهوهى زانياريياككان

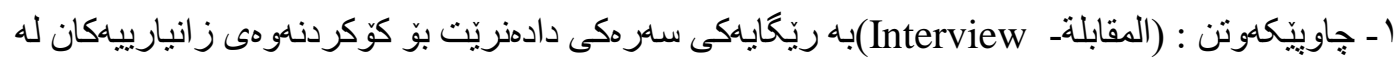

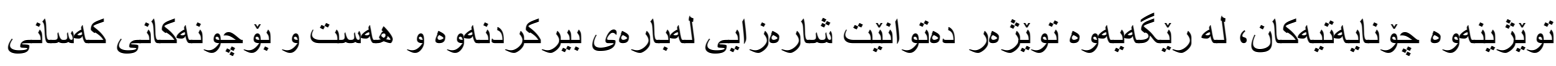

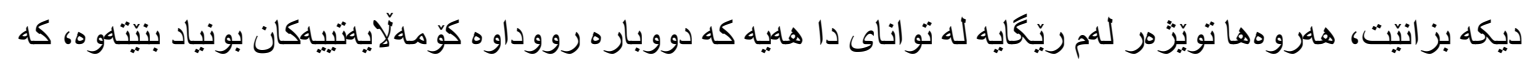

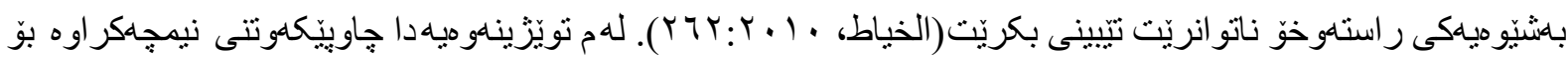

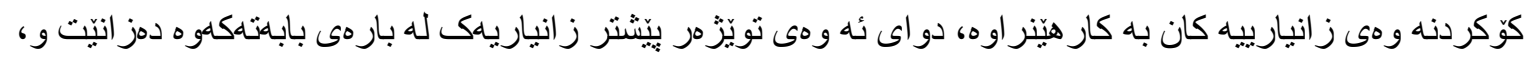

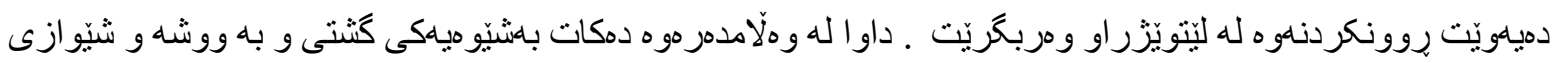

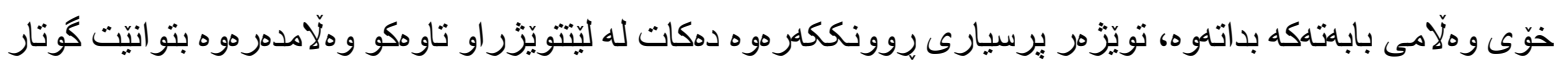

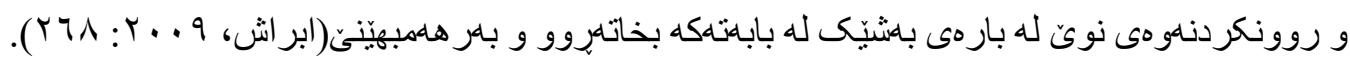

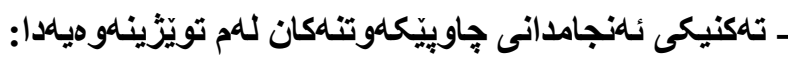

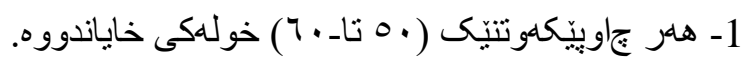




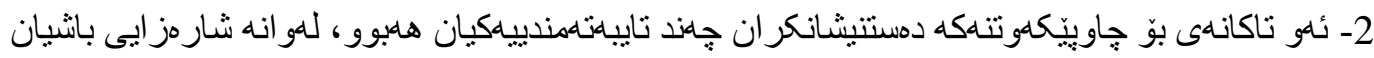

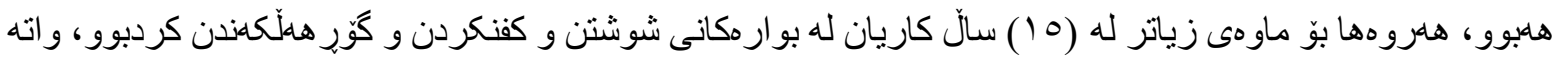

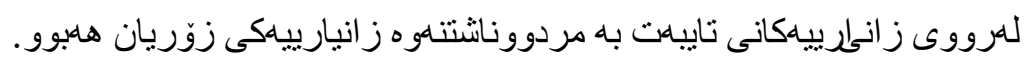

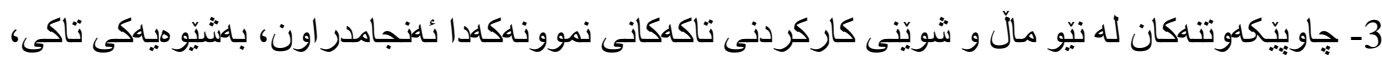

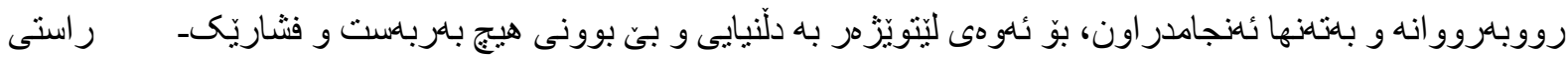

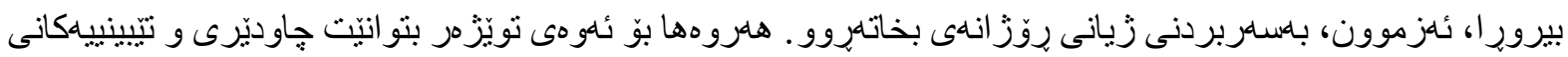
خوّى باهووردى توّمار بكات.

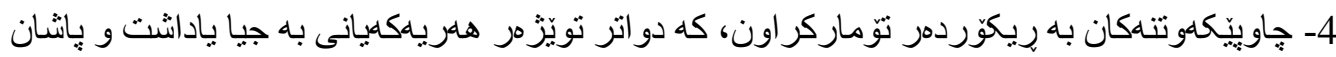
باكنووس كردووه.

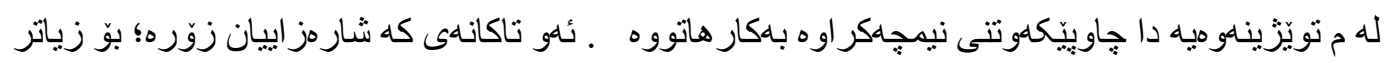

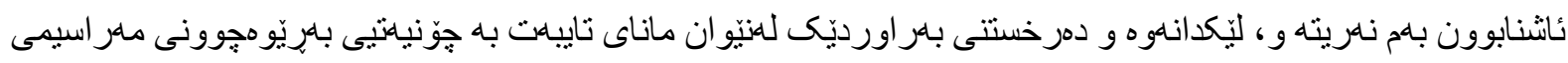

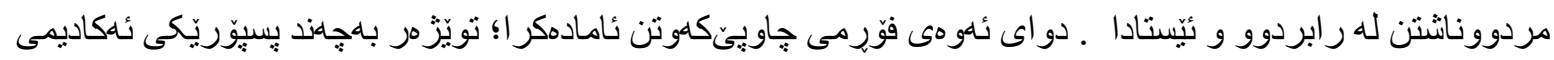

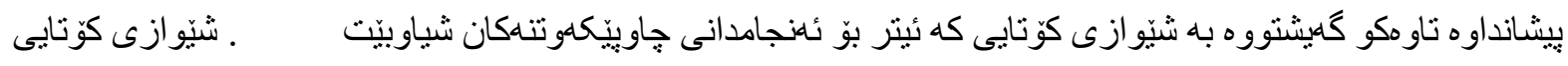

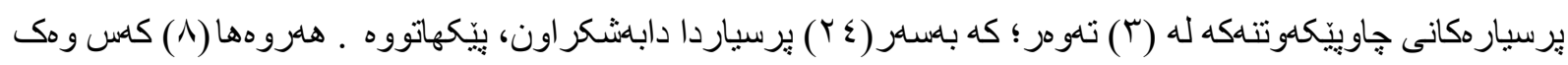

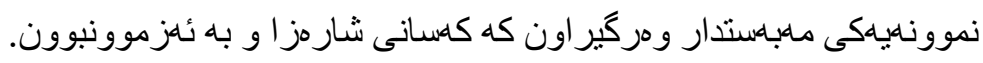

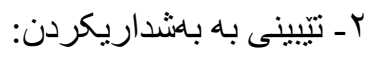

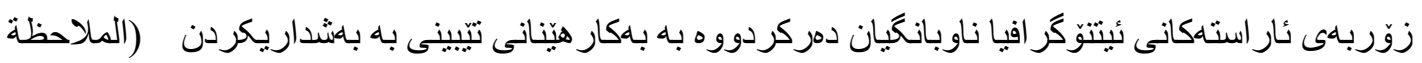

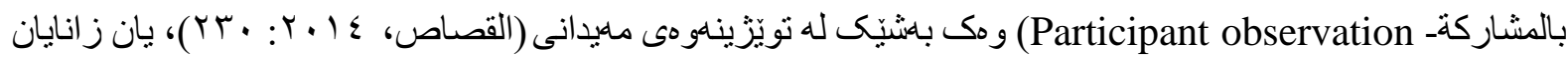

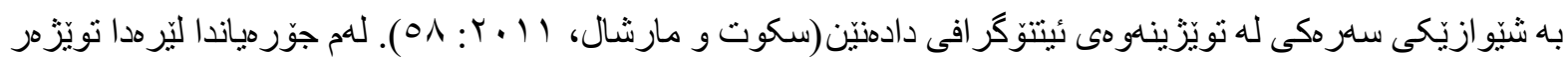

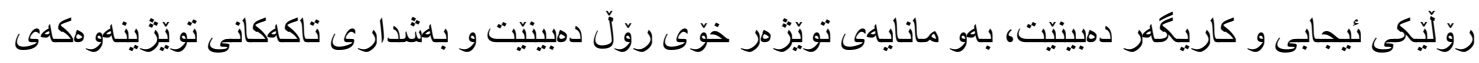

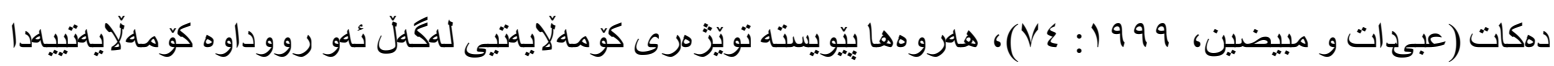

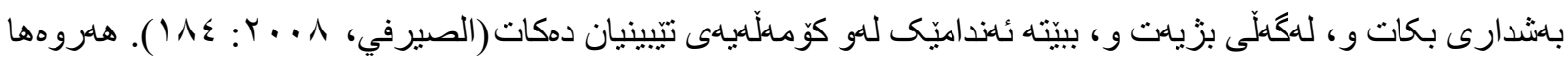

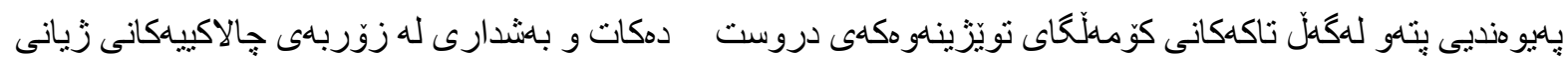

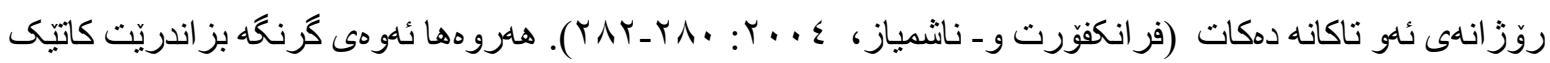

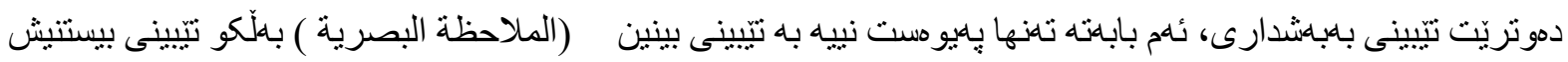

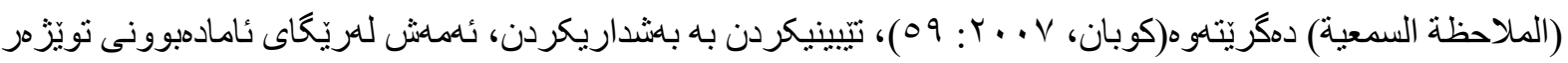

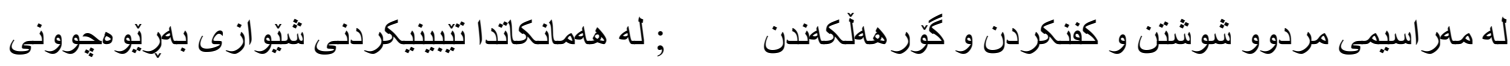

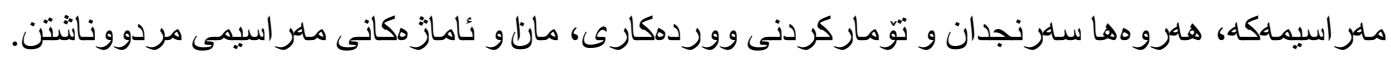

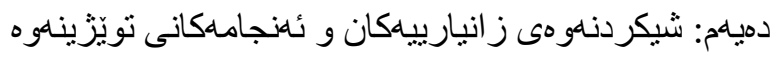
يهك: خستناروو و شيكر دناوهى ز انيارييككانى تويّزينهوه

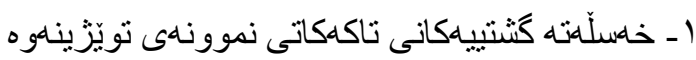

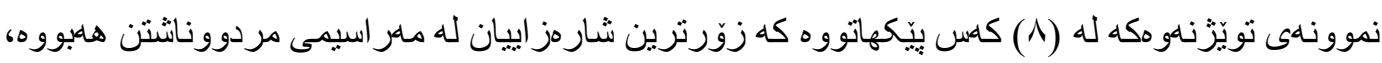

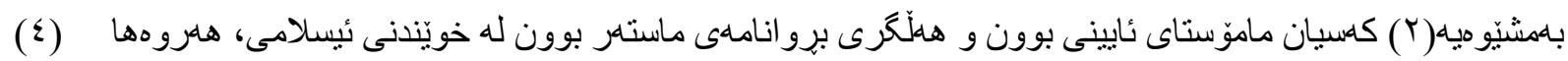




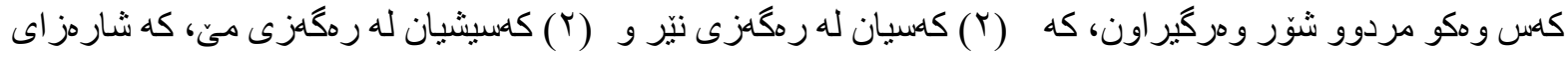

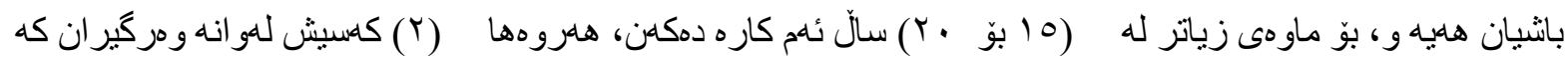

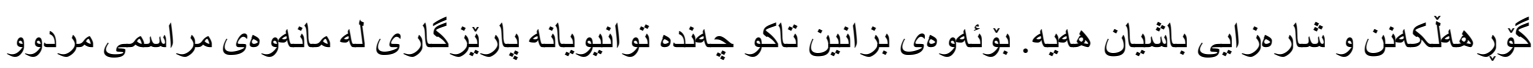
ناشتنن بكمن.

$$
\begin{aligned}
& \text { r _ شيكردنهوهى ز انيارييه تايبهنييهكانى تويزّزينهوه } \\
& \text { 1 ـ دابونهرينى مردووناثنتن: }
\end{aligned}
$$

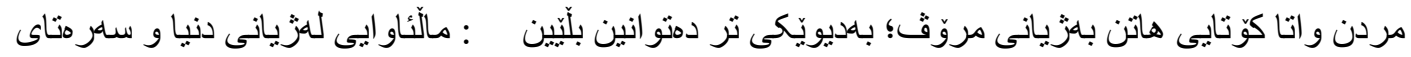

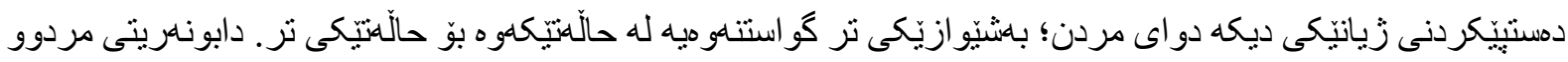

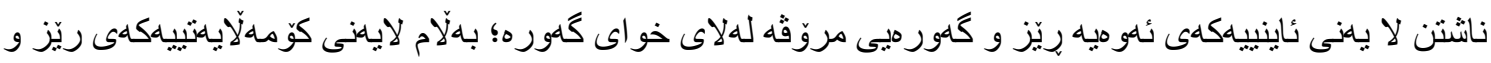

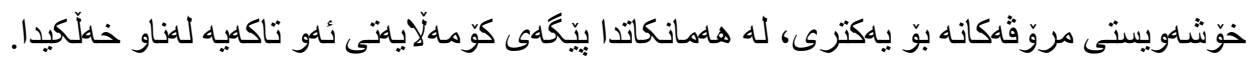

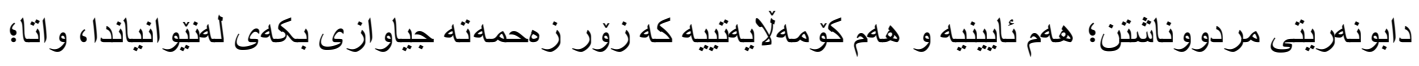

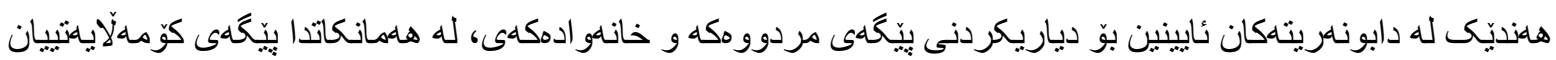

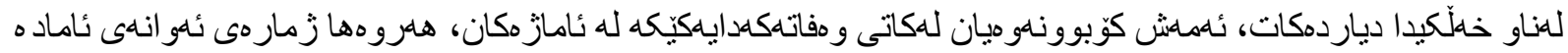

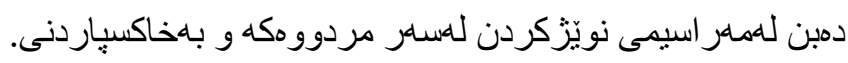

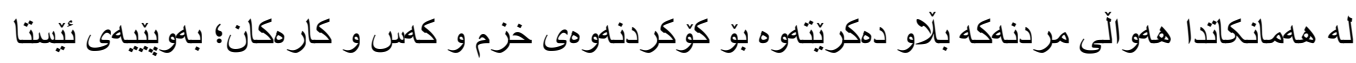

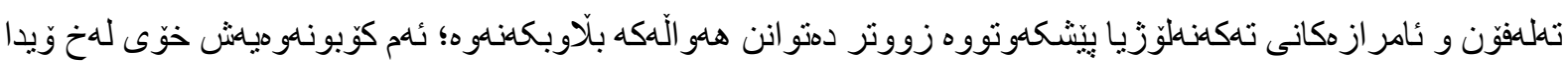

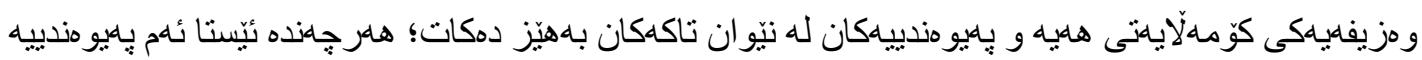

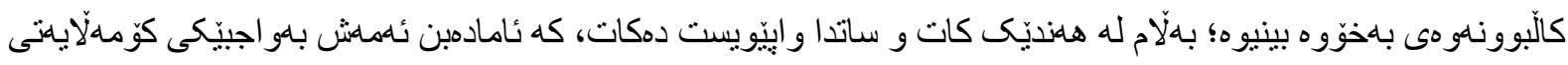

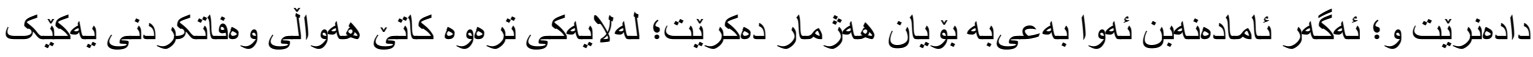

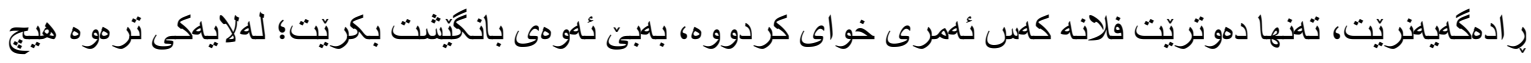

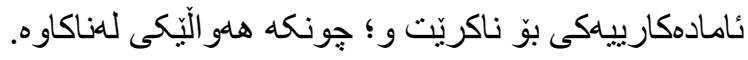

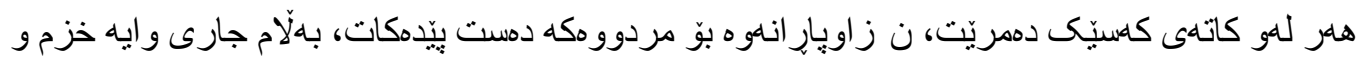

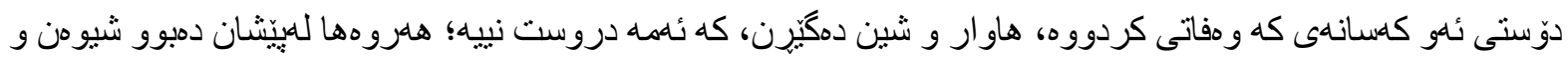

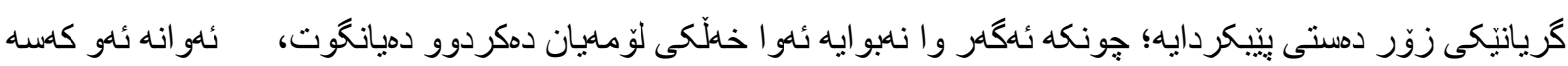

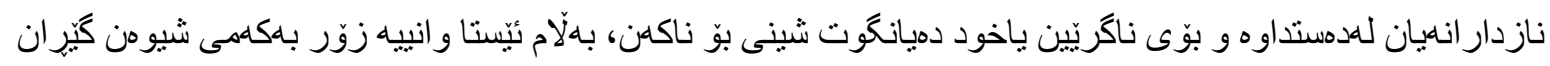

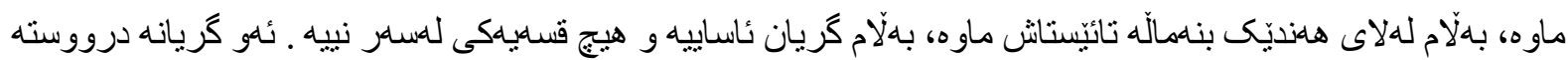

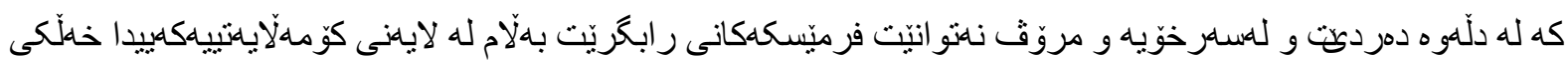

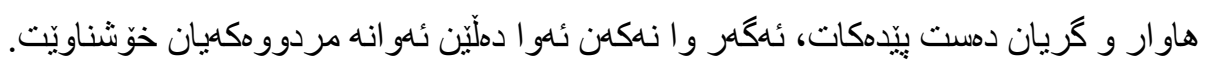

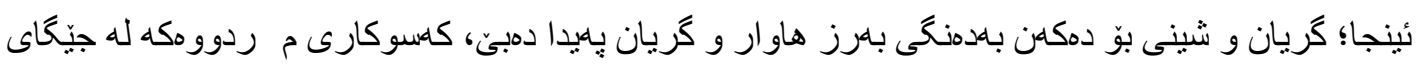

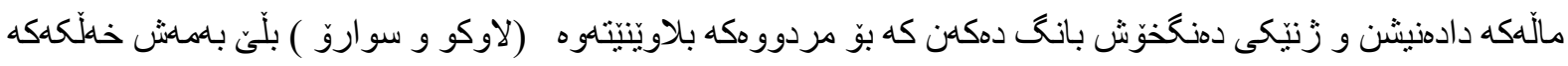

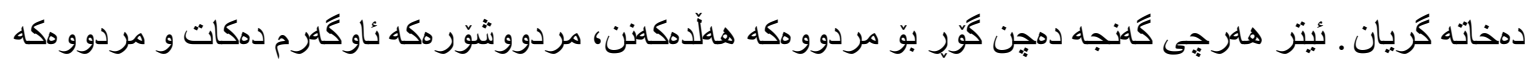

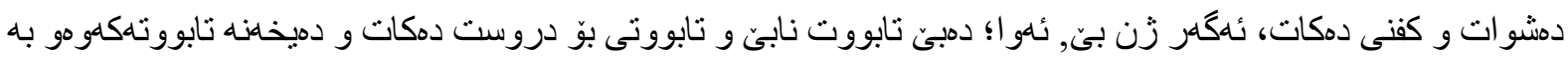




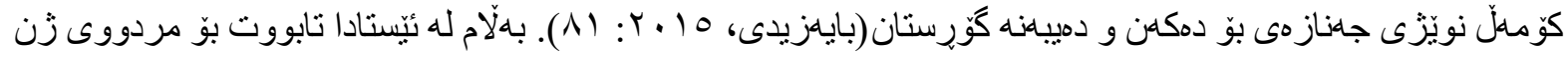

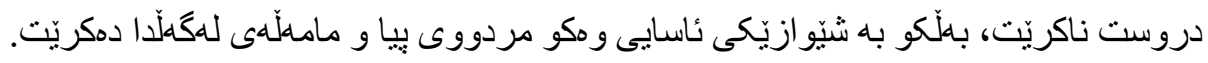

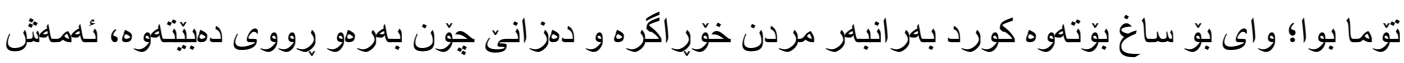

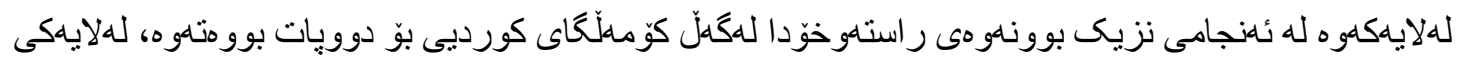

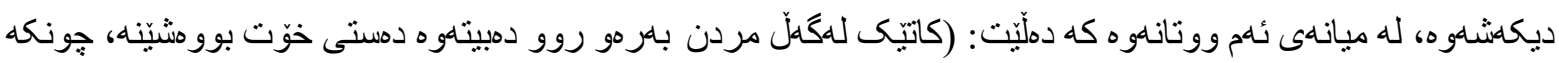

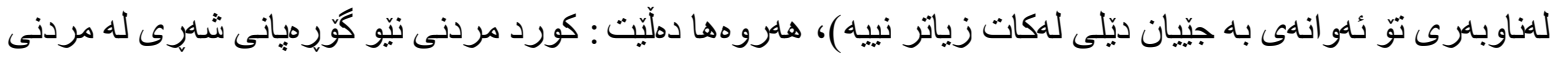

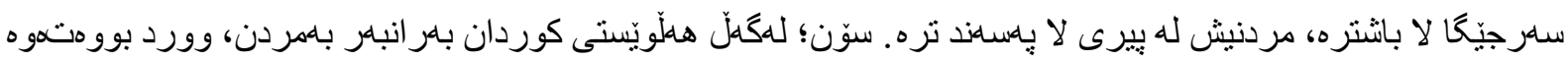

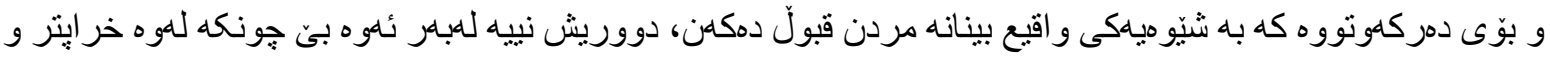

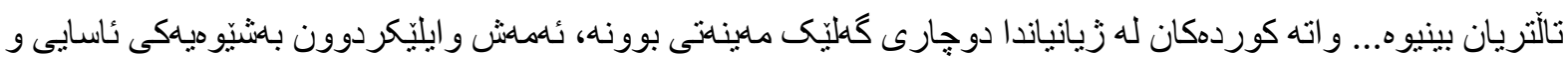

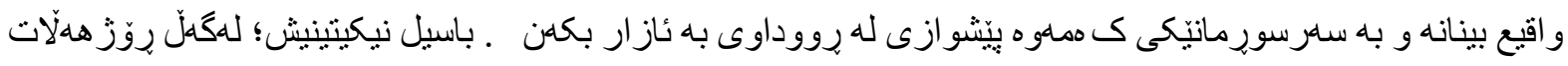

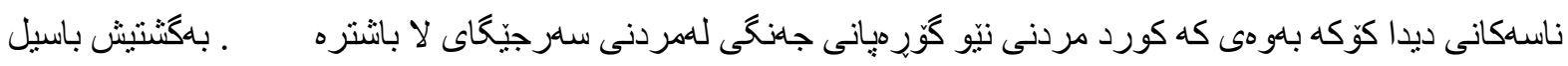

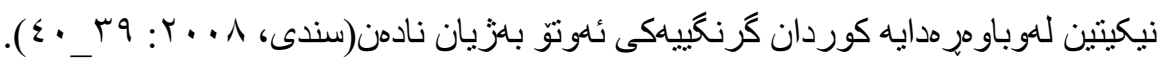

\section{r ـ ئامادمكردنى مردوو بوّ شوشتن:}

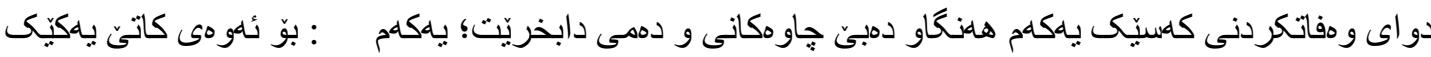

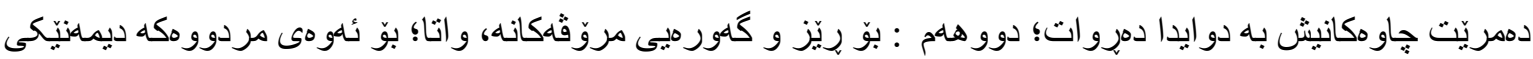

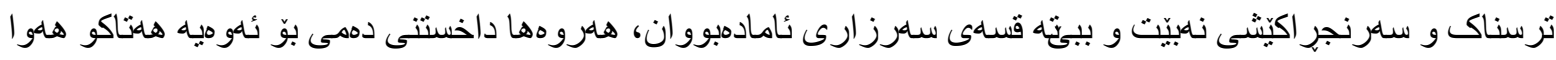

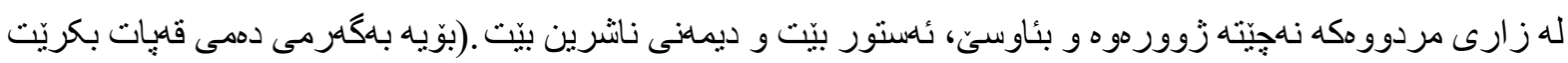

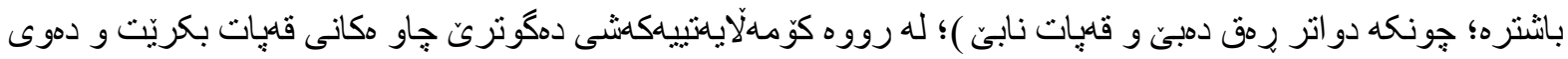

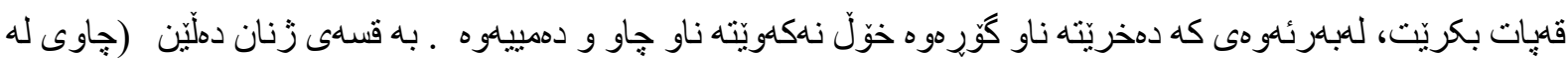

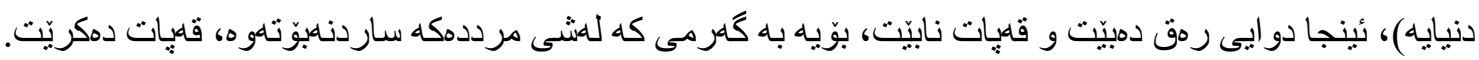

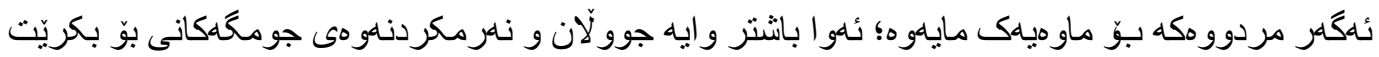

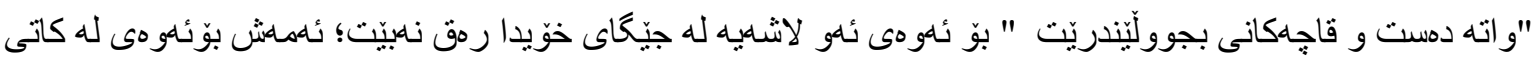

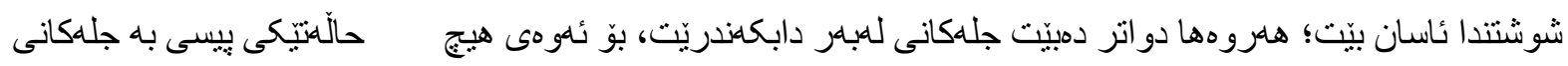

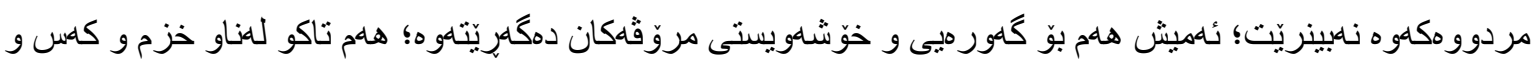

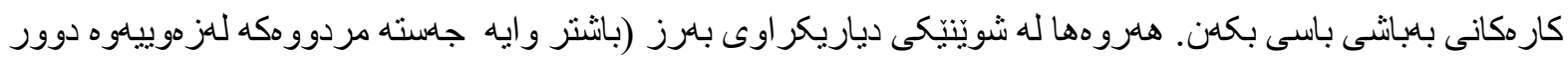

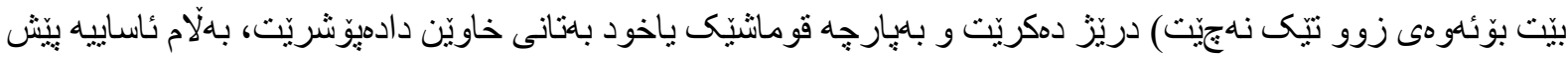

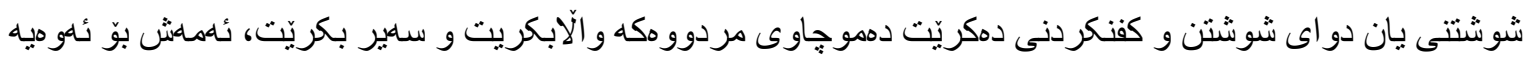

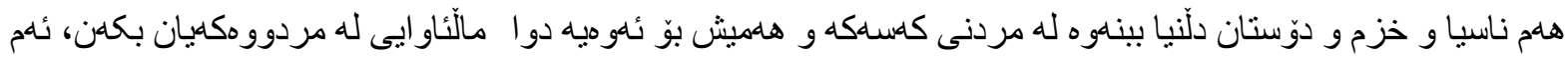

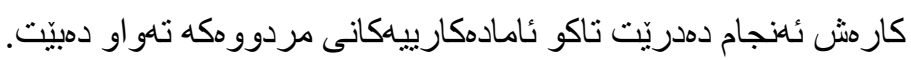

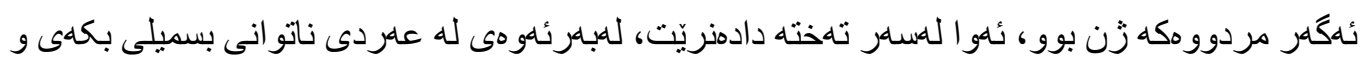

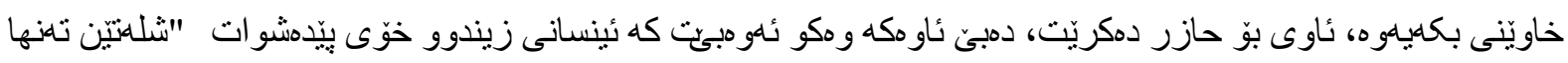

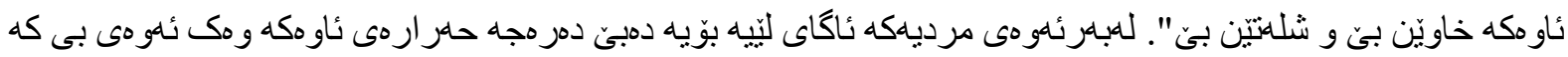

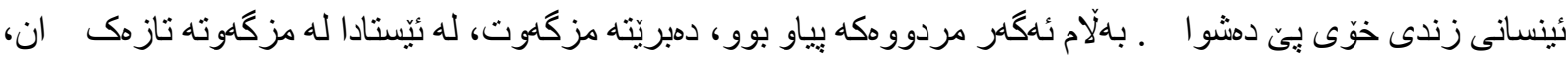




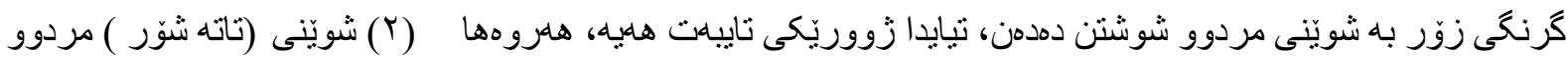

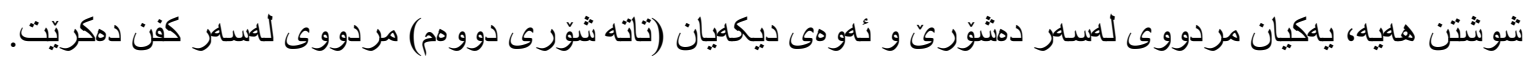

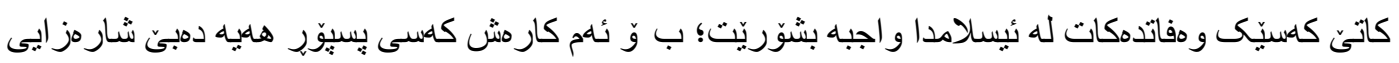

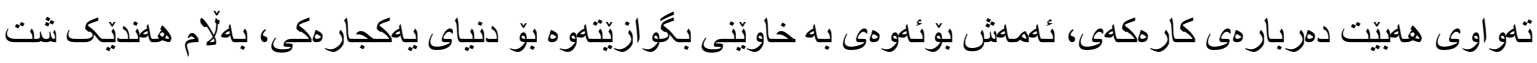

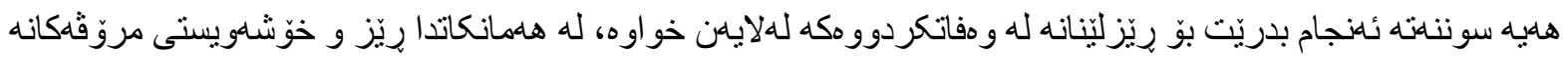

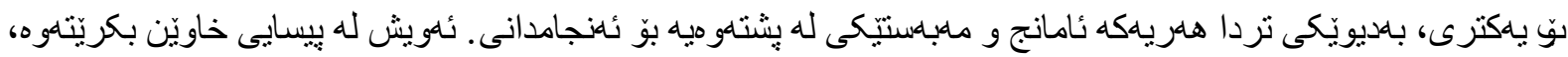

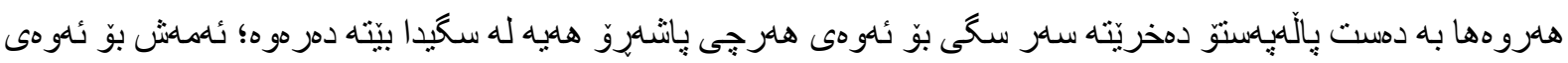

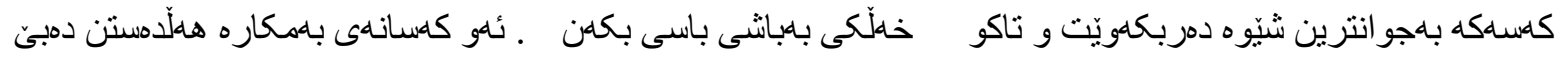

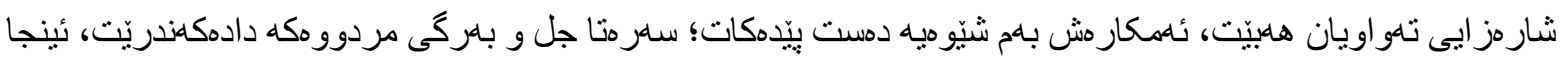

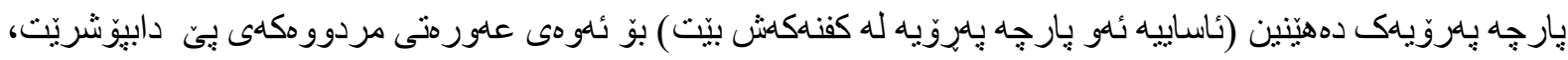

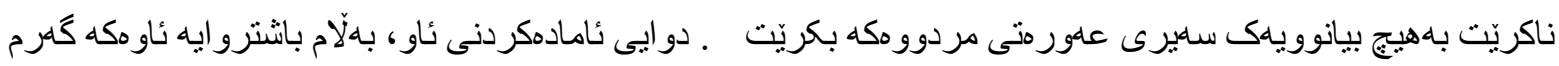

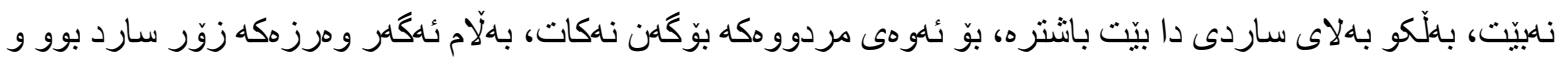

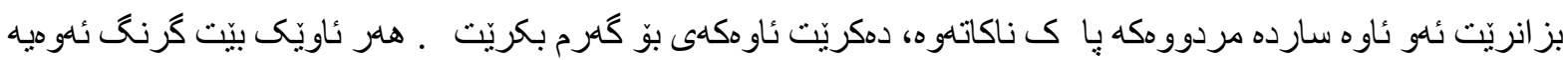

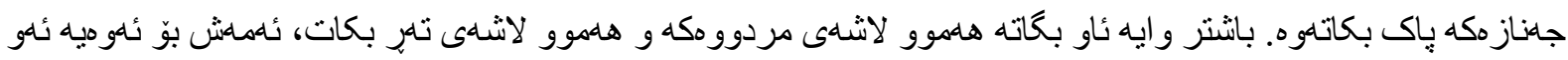

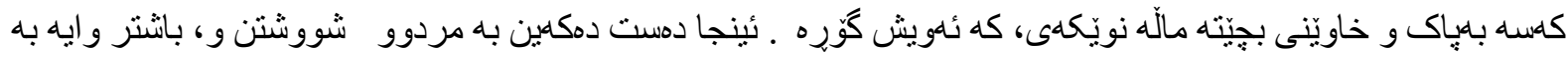

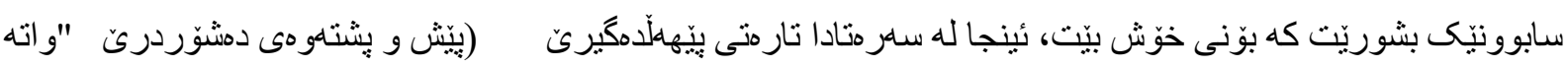

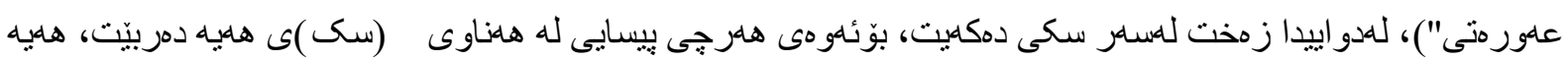

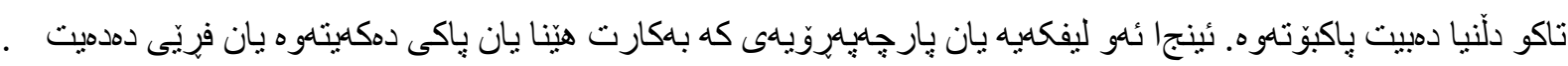

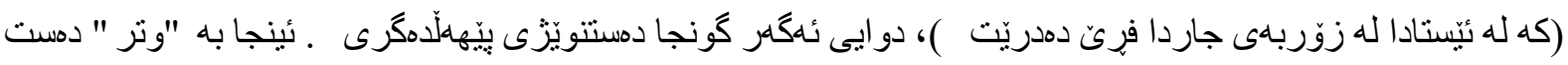

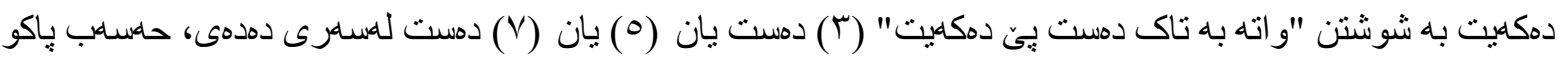
خاويّنى مردياكهى.

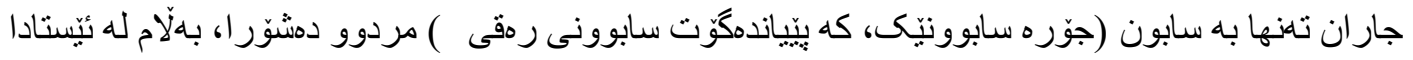

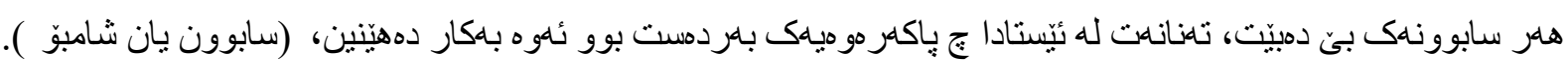

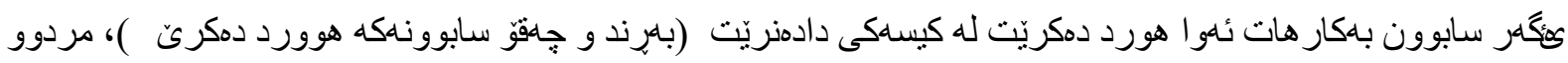

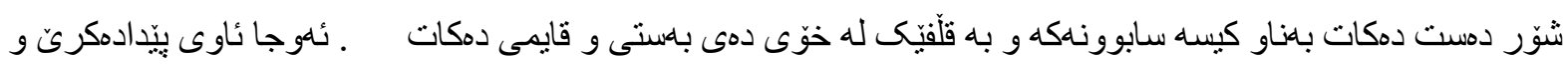

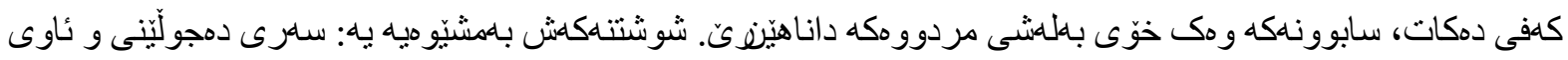

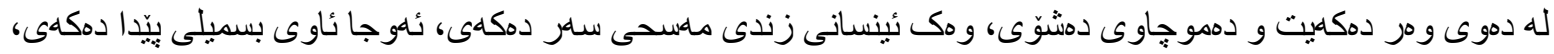

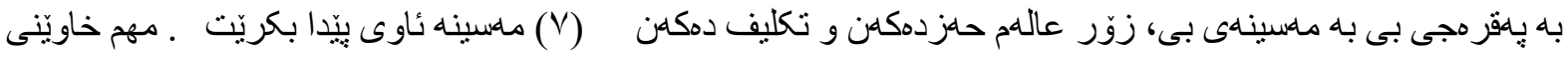

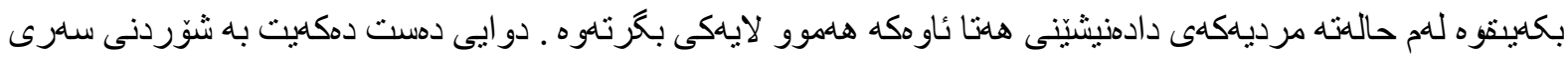

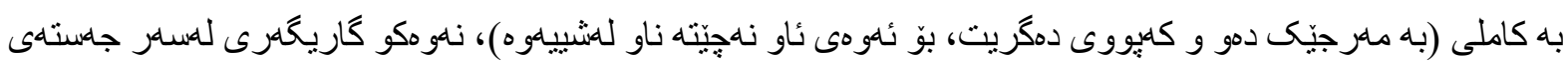

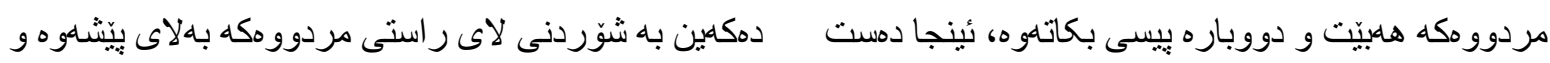

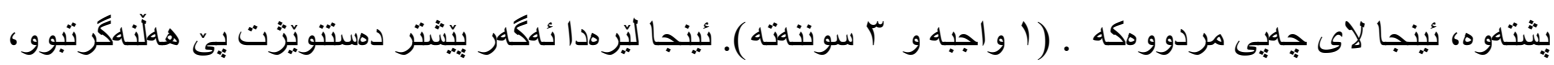

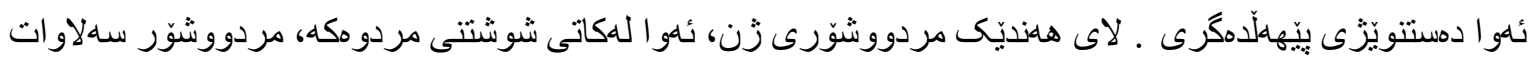

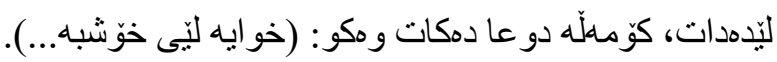




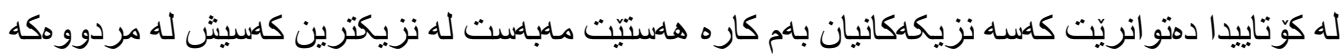

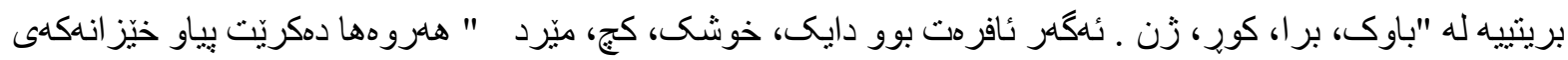

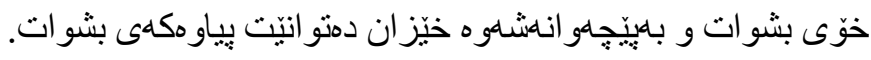

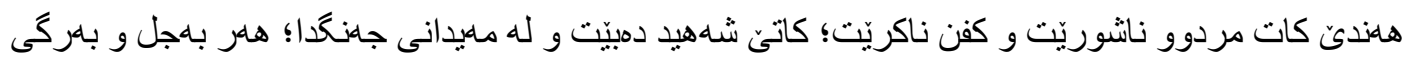

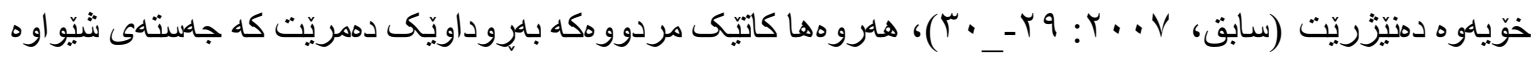

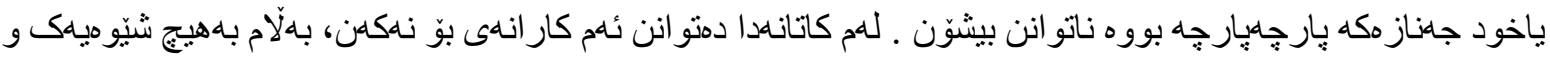

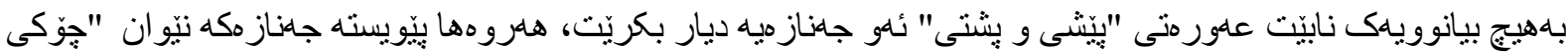

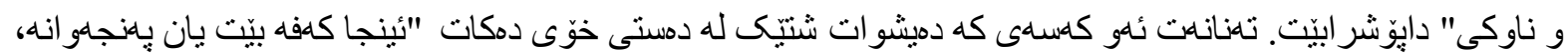

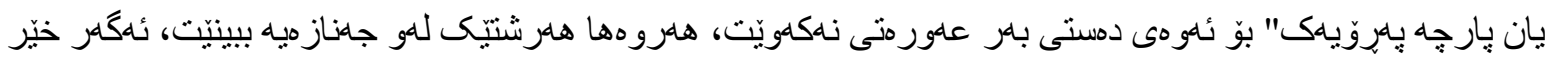

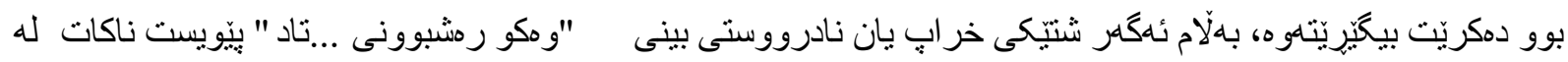

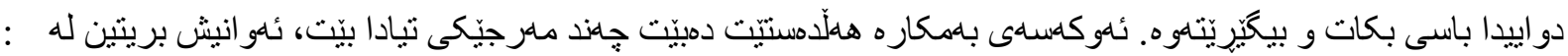

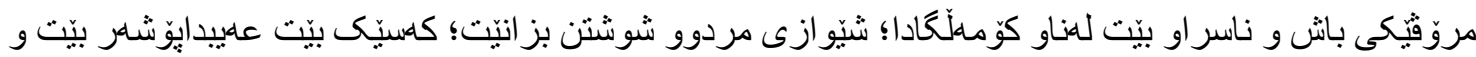

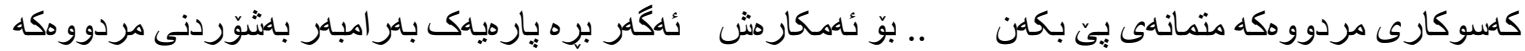

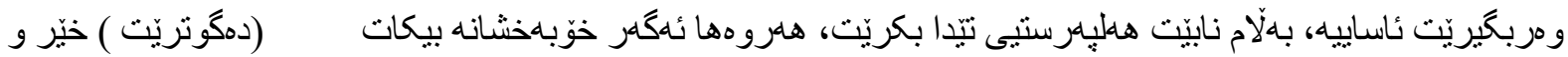

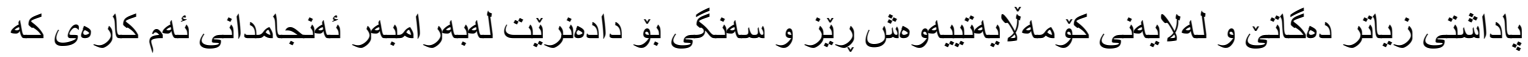
دميكات.

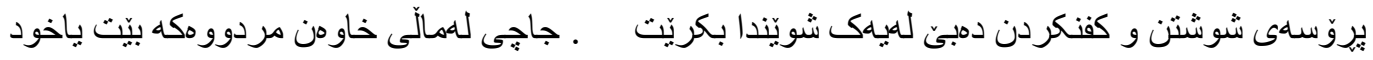

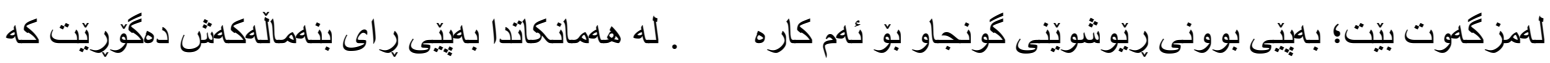

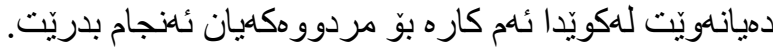

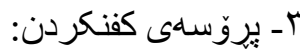

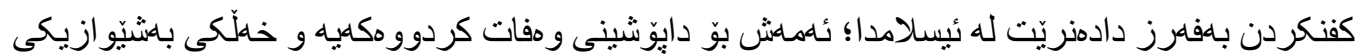

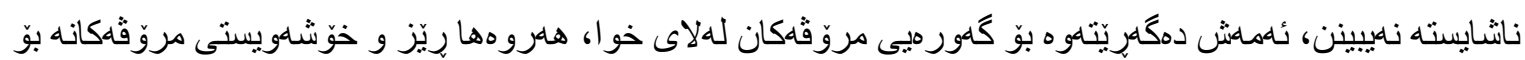
ياككترى كاتى بام كاره هالّدمستن.

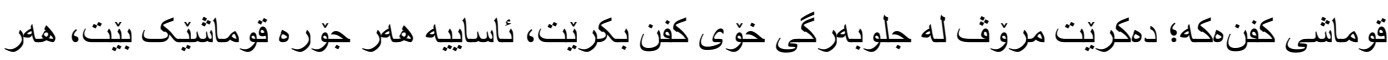

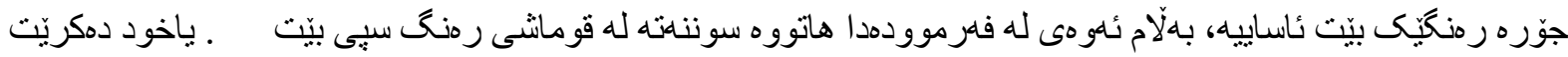

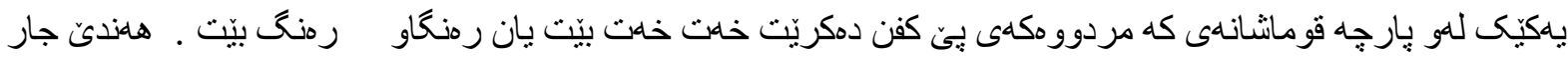

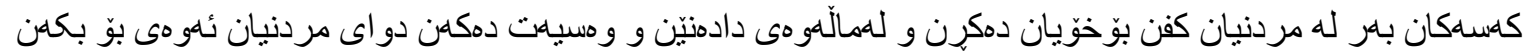

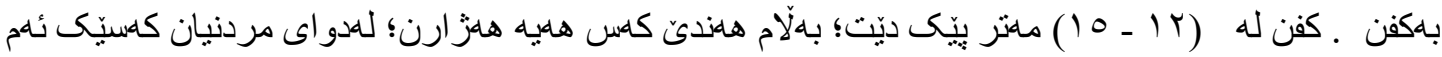

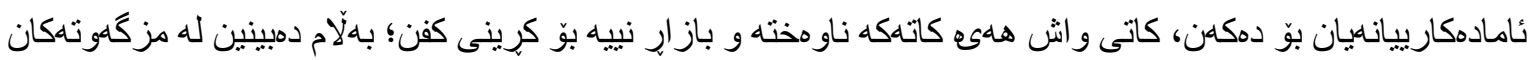

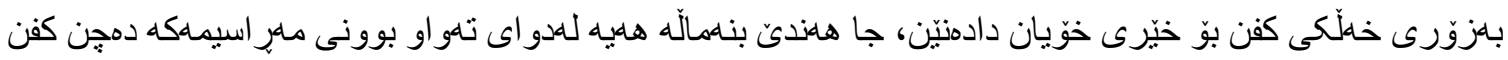
دمكرن و له شوينى كفناكهى بهكاريان هيناوه دايدهنيناهوه.

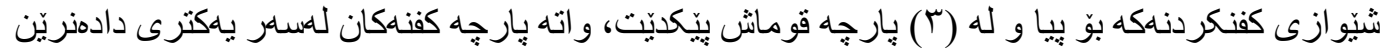

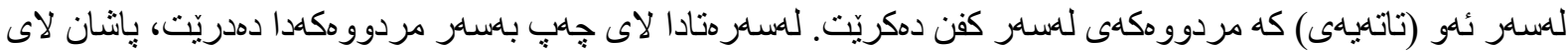




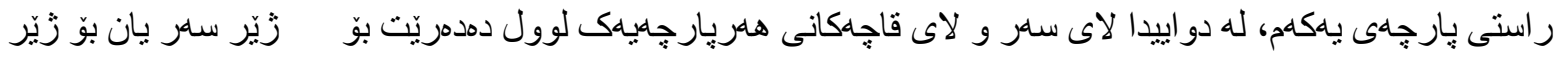

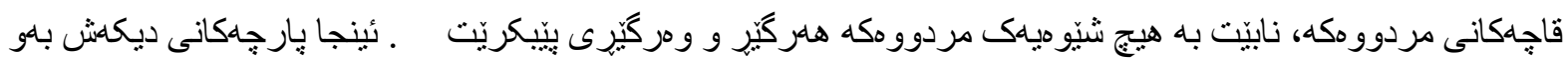

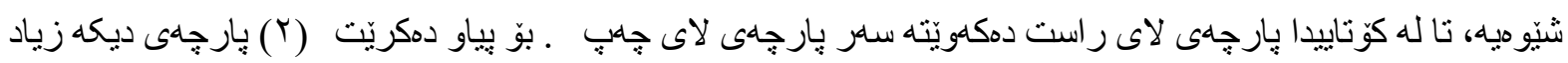

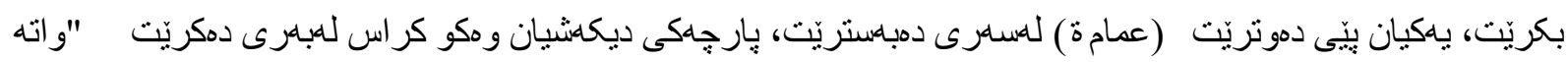

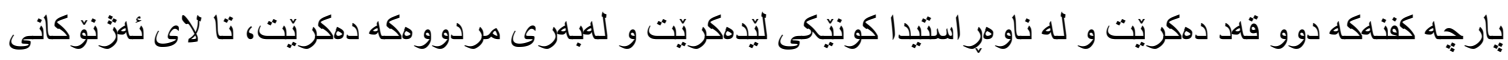

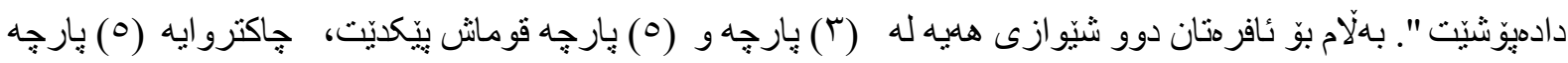

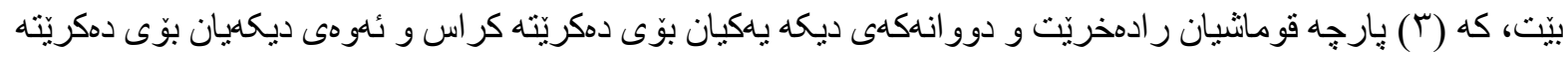

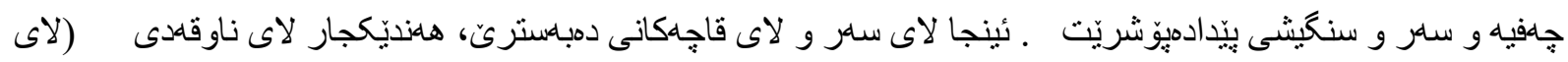

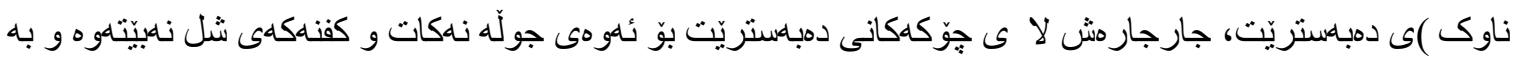

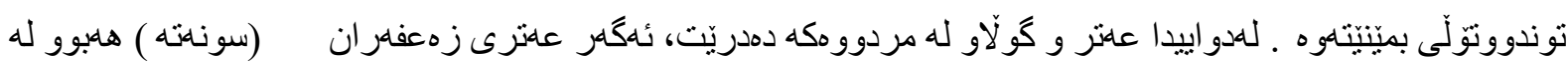

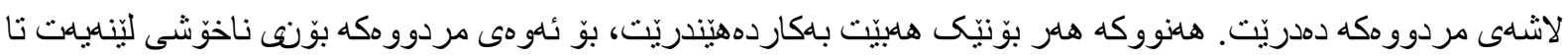

بهخاك دمسيِّردريّت.

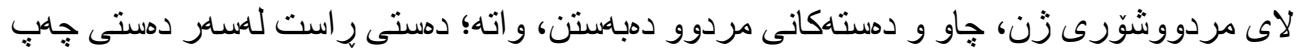

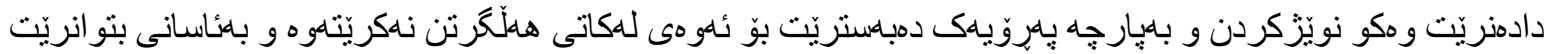

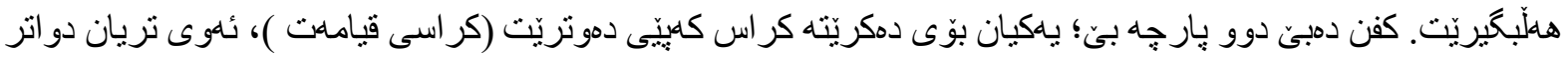

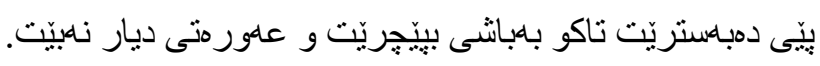

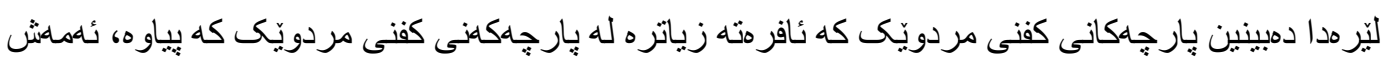

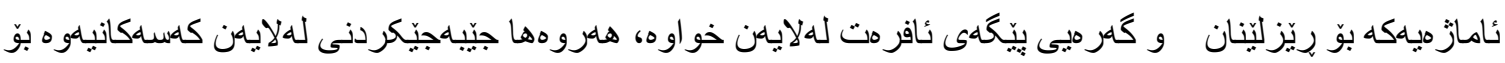

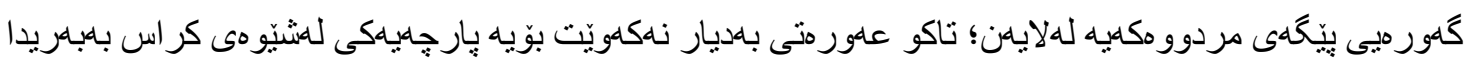

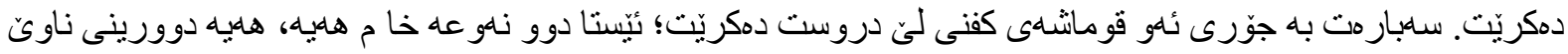

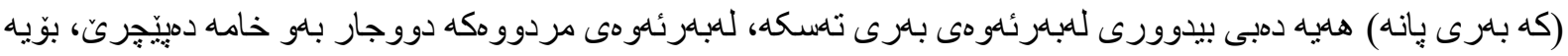

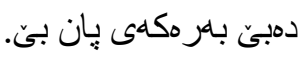

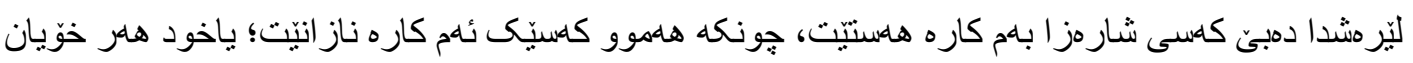

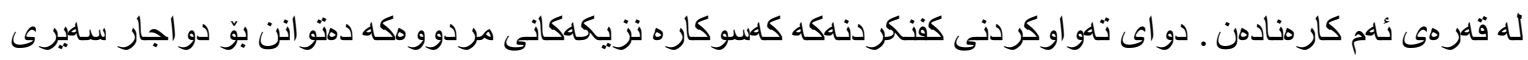

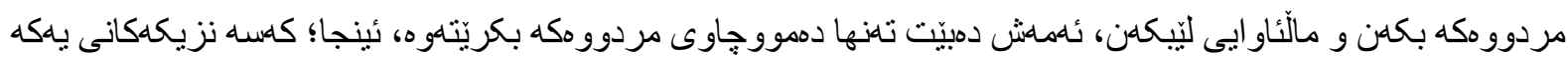

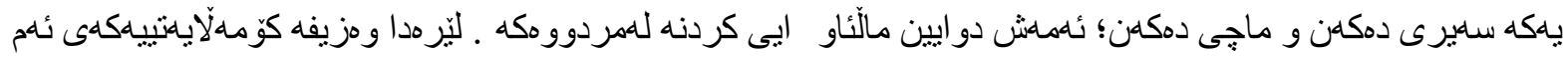

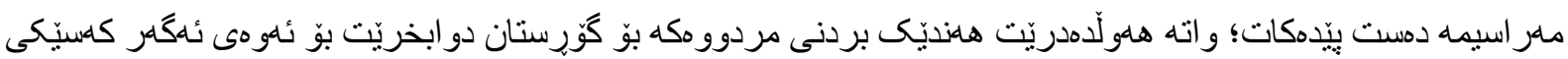

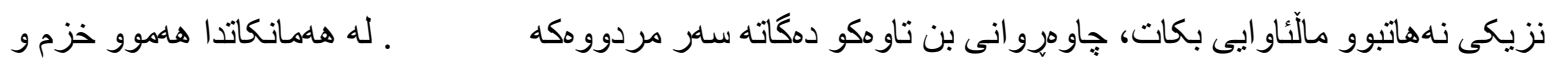

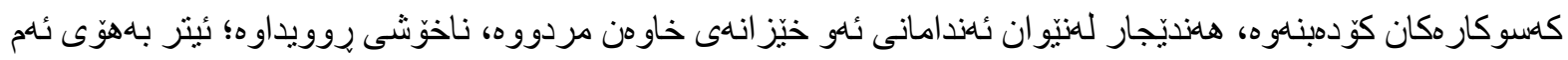

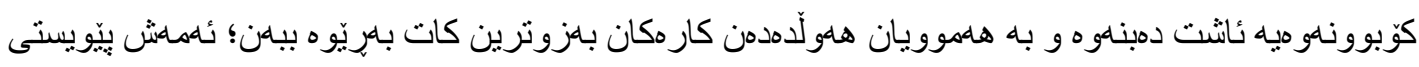

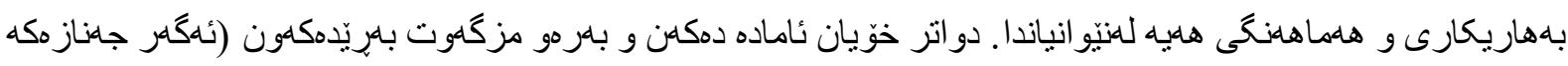

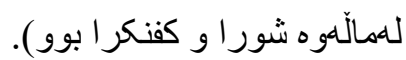




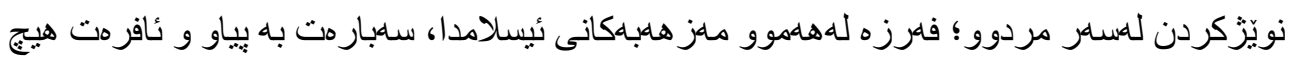

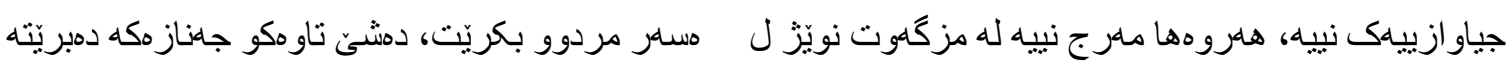

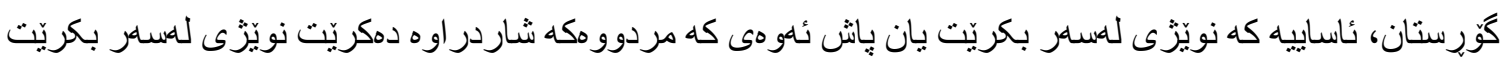

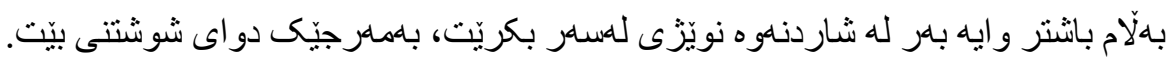

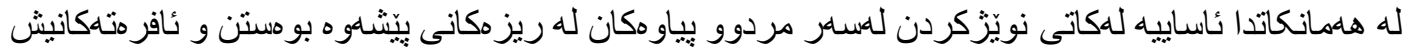

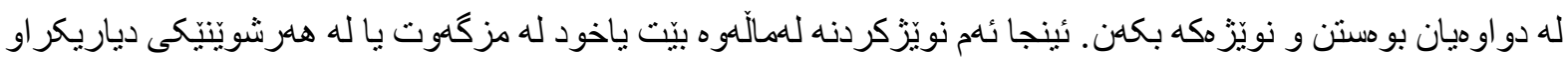

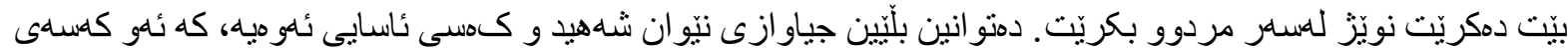

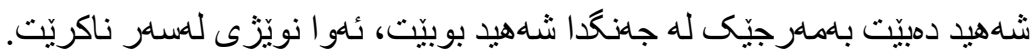

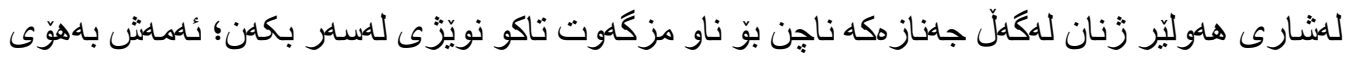

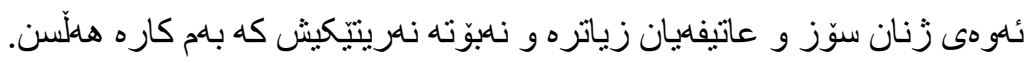

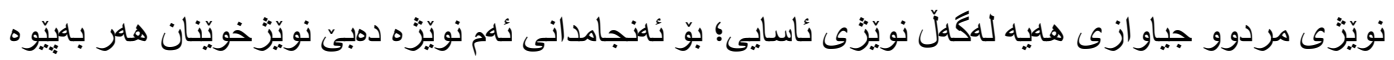

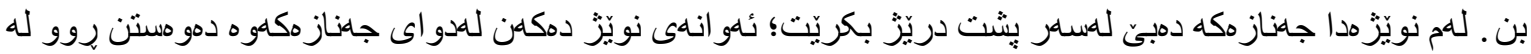

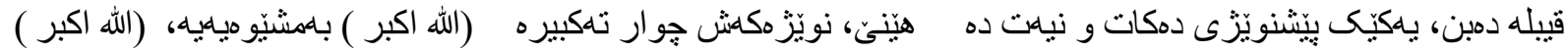

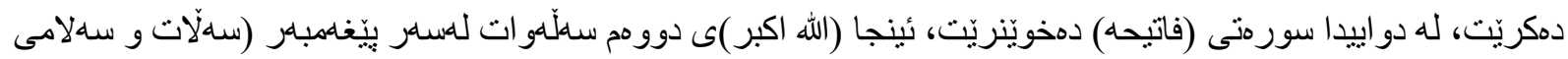

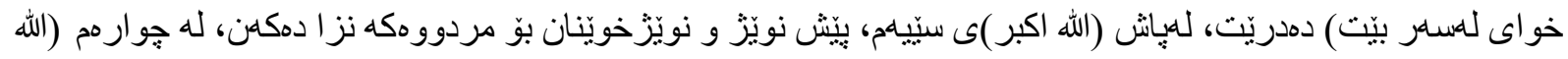

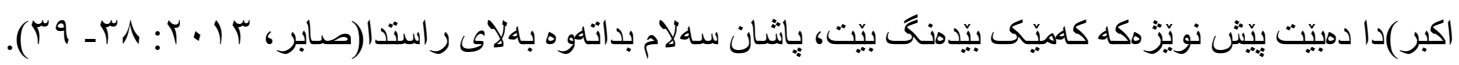

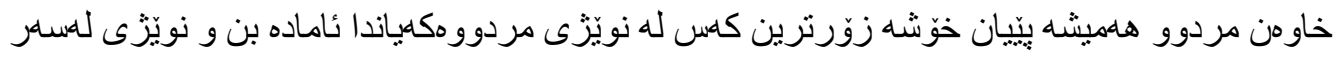

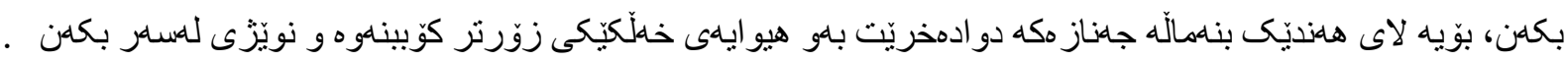

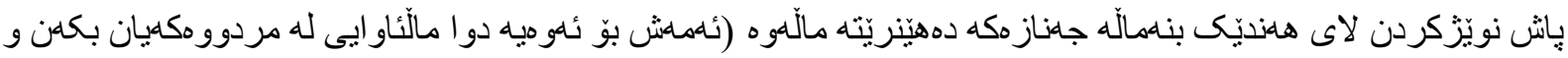

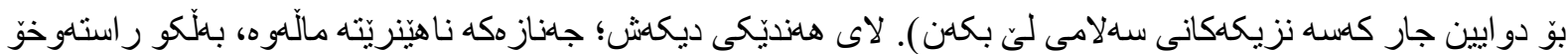

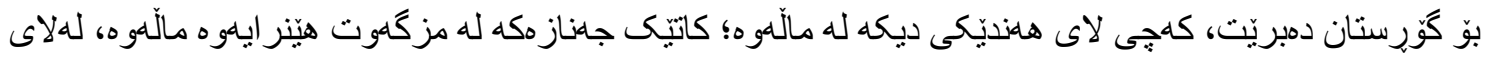

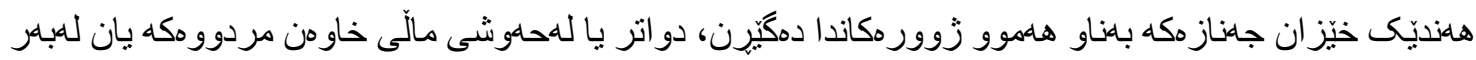

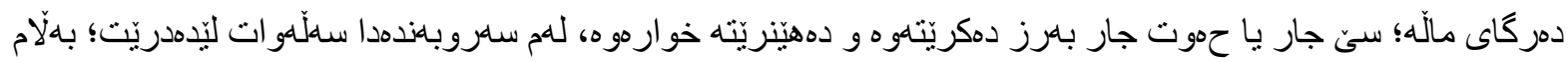

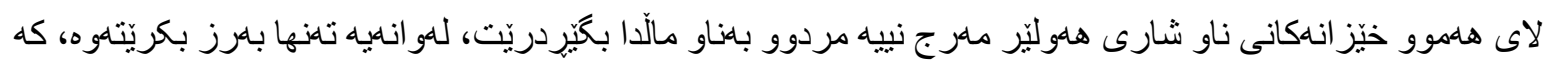

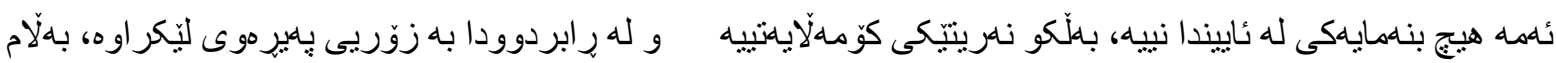

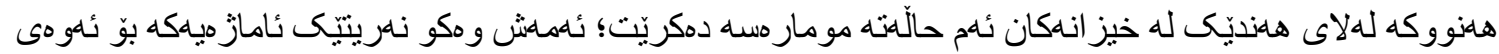

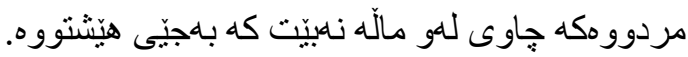

$$
\text { 6- بازِيَوْجورونى مردوو ناشتن: }
$$

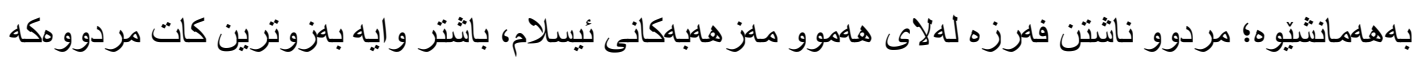

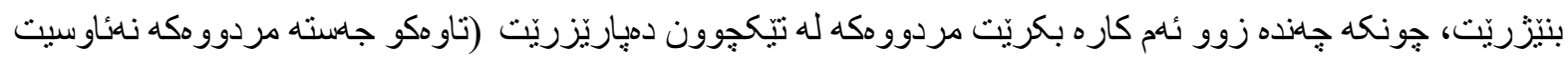

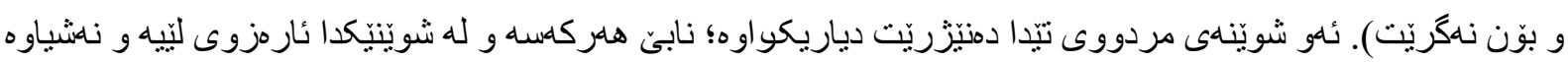

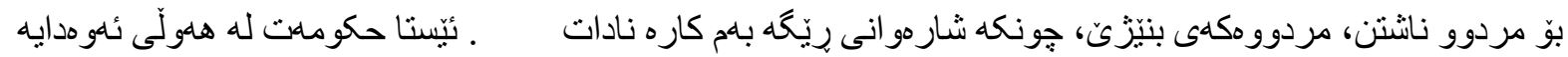

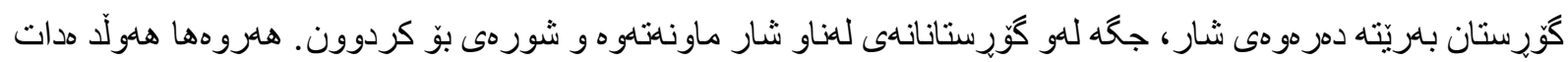




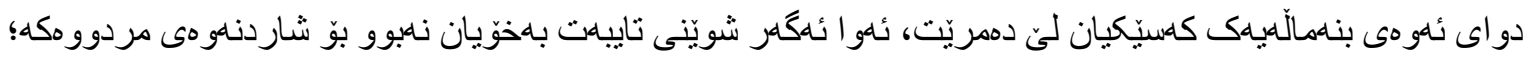

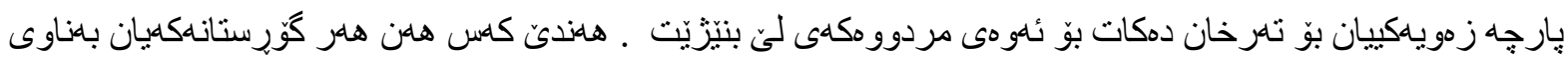

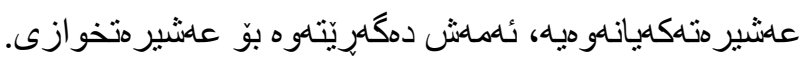

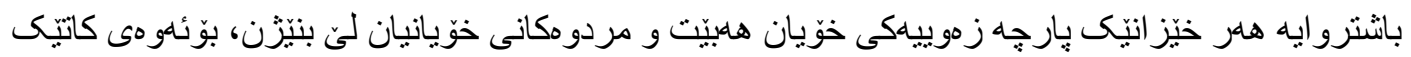

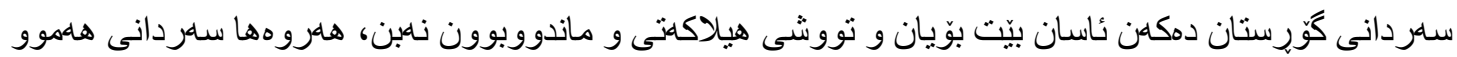

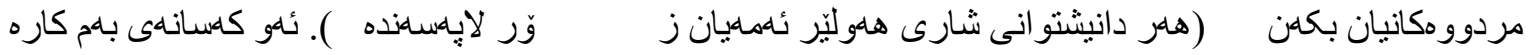

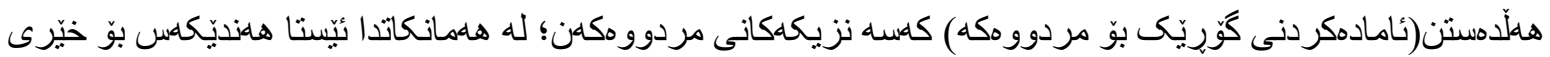

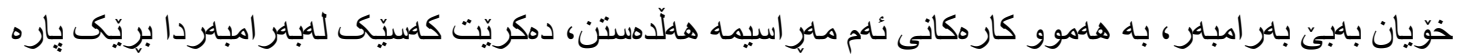

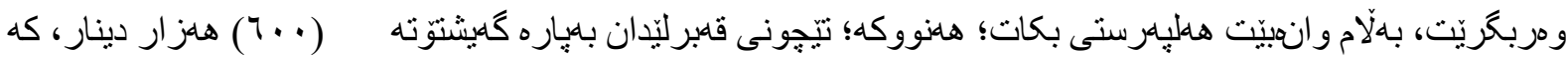

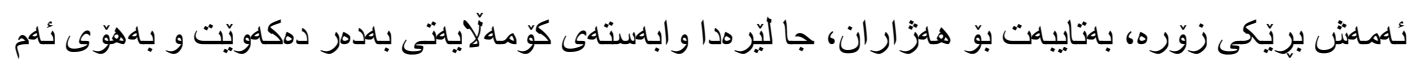

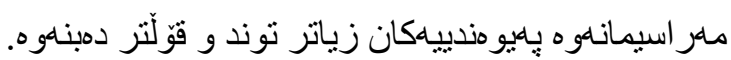

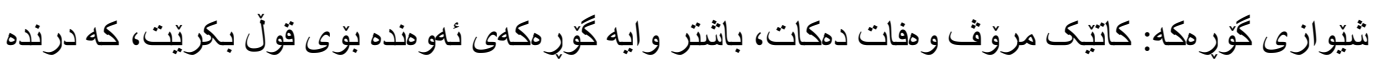

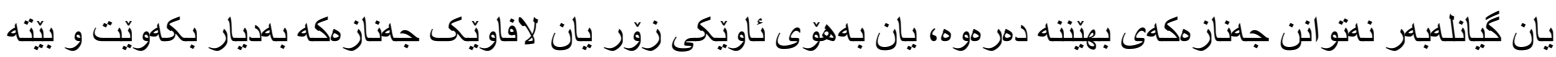

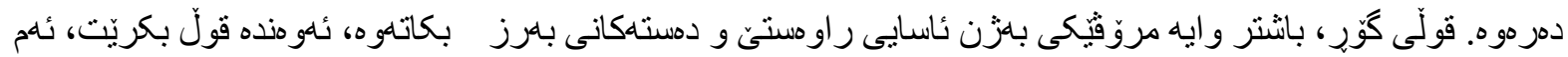

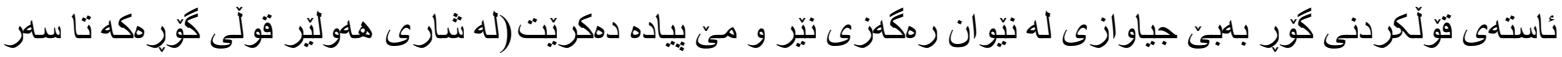

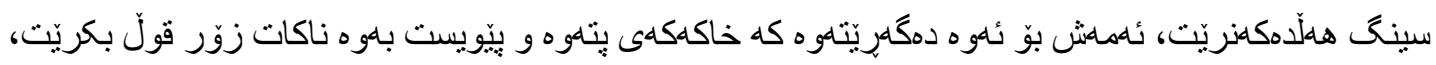

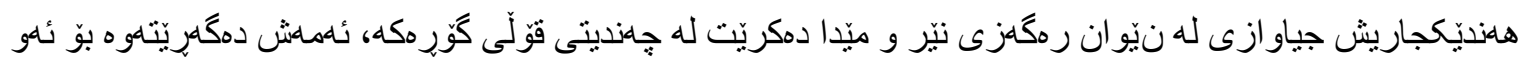

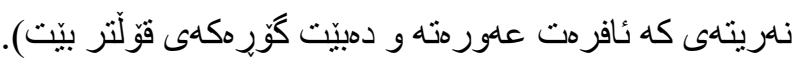

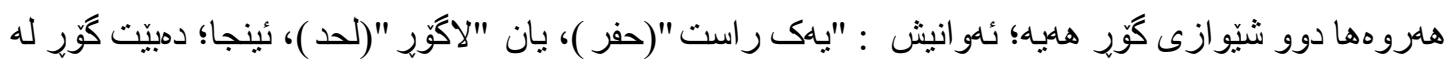

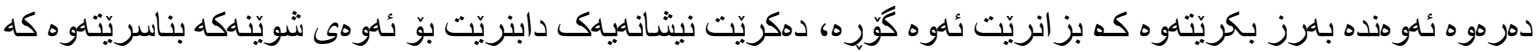

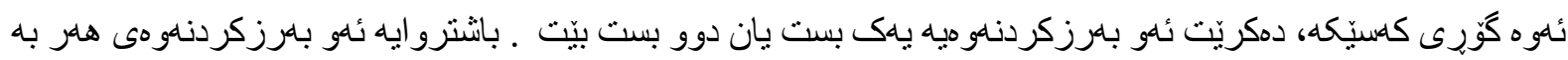

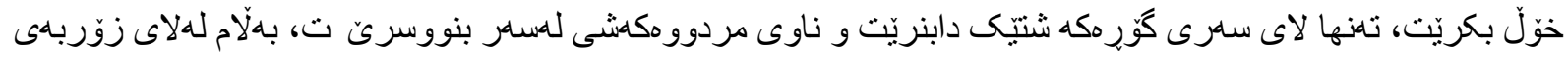

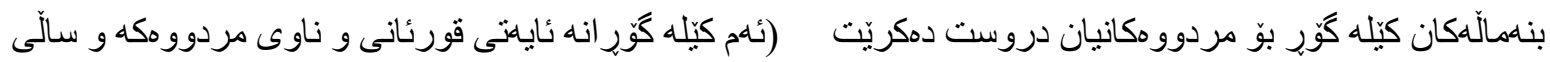

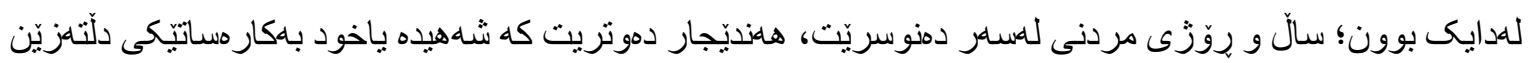

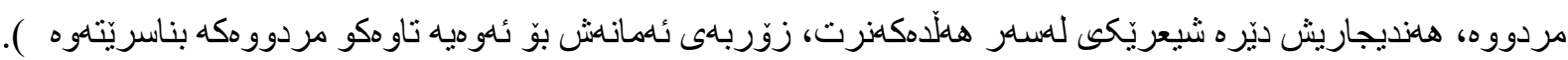

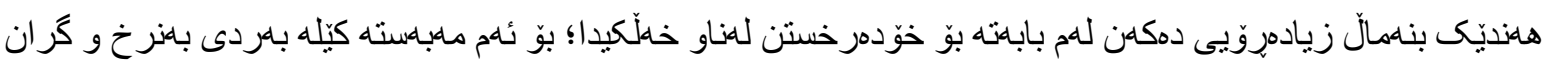

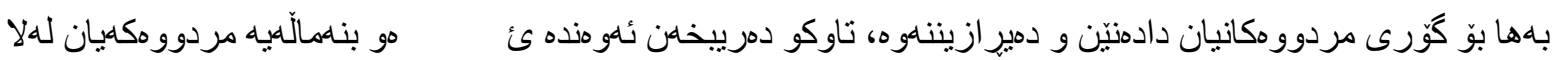

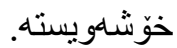

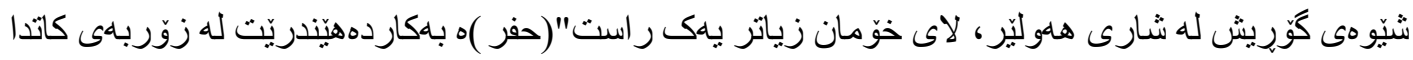

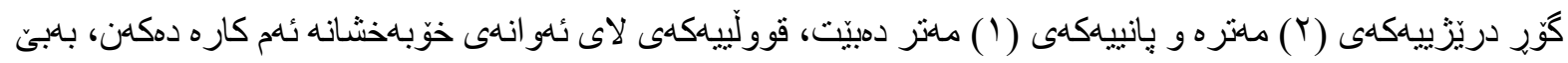

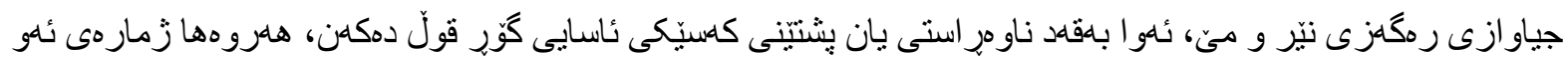

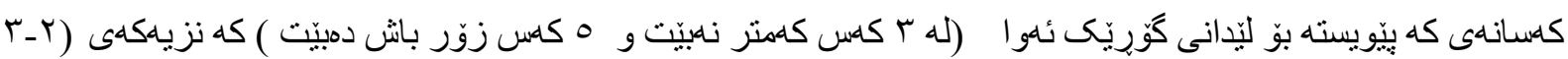

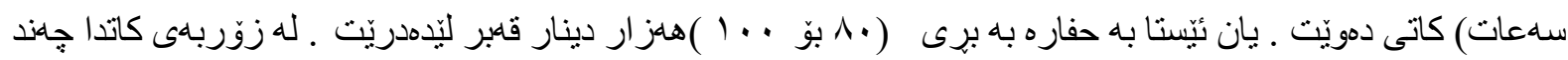

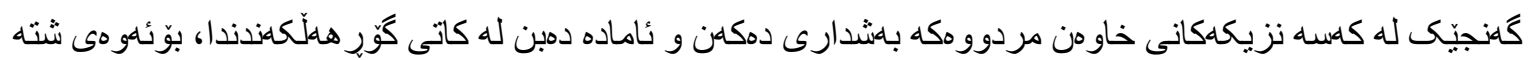




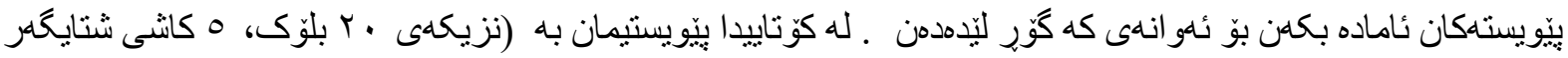

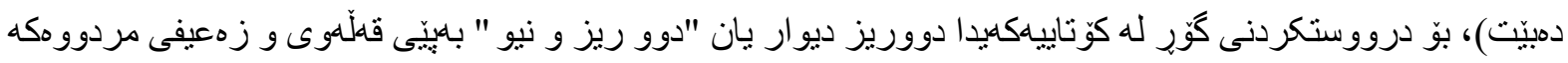

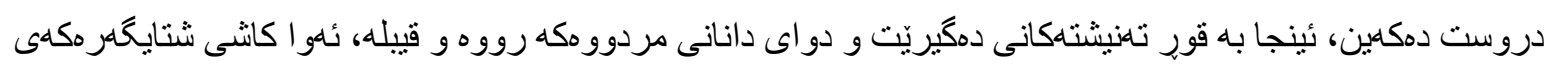

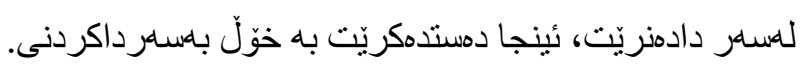

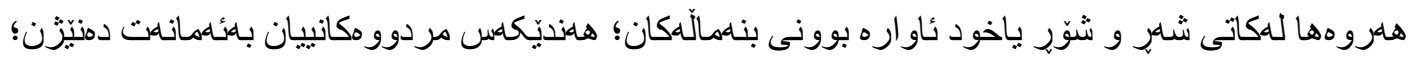

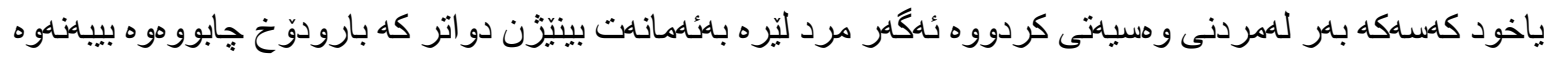

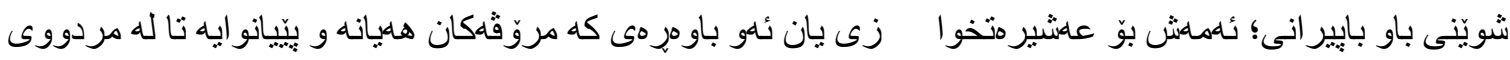

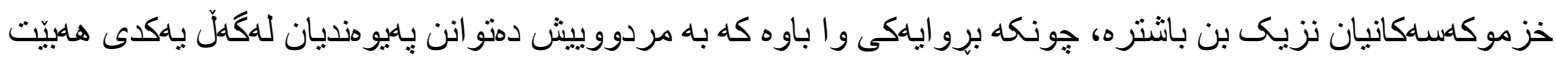

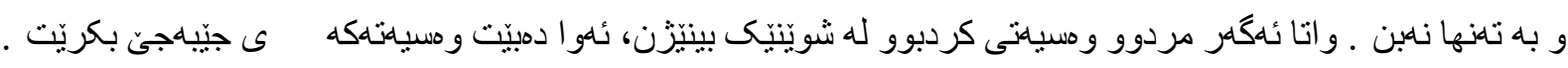

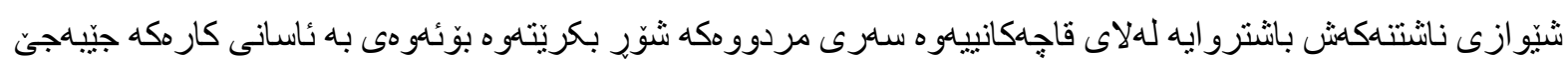
بكريت.

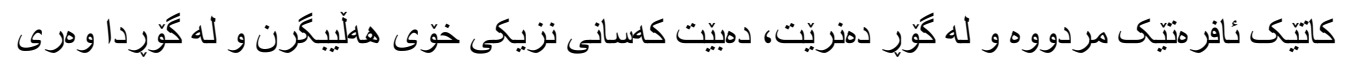

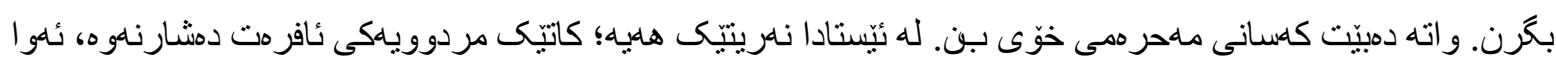

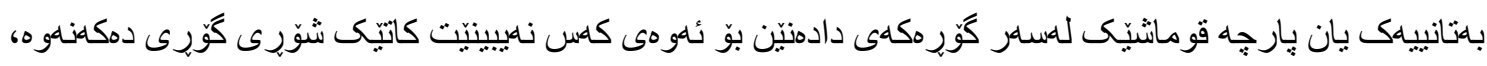

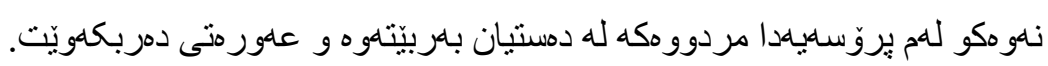

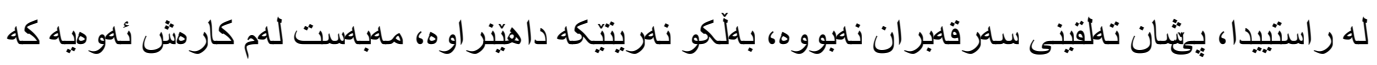

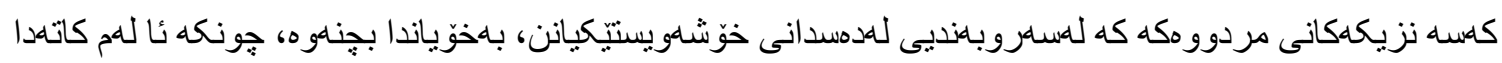

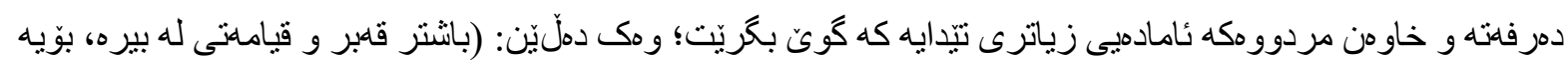

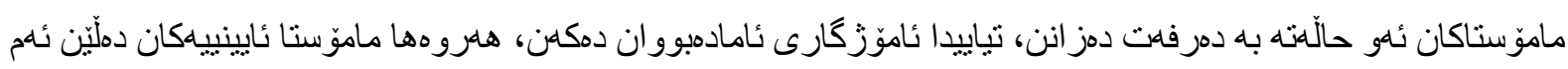

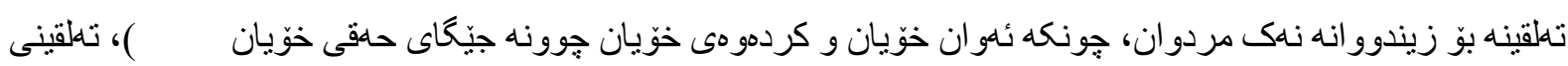

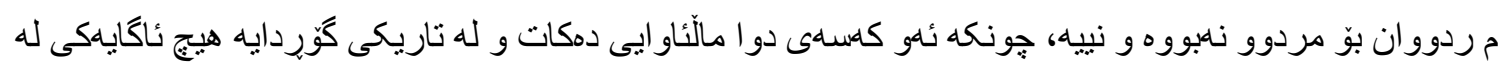

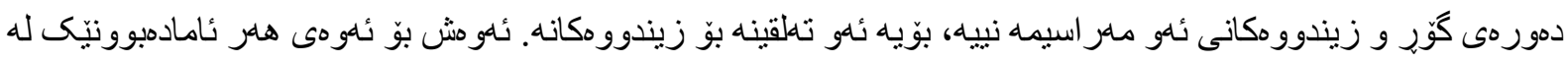

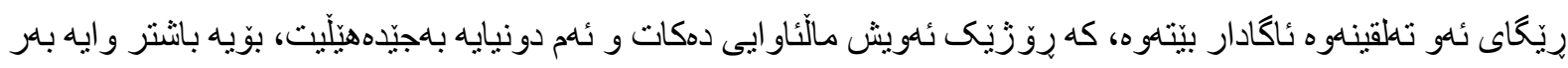

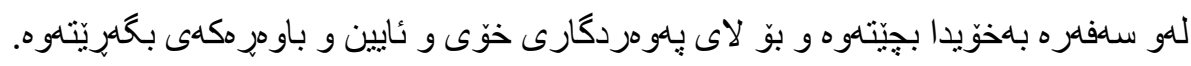

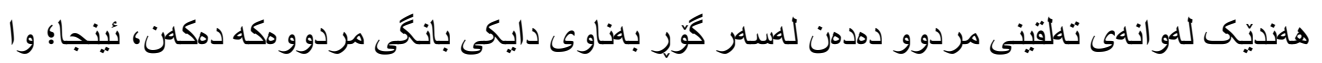

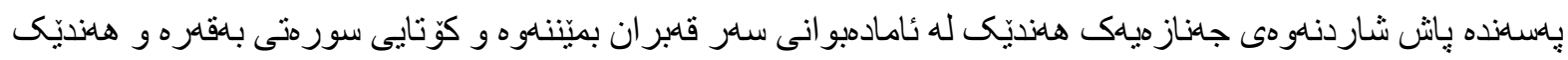

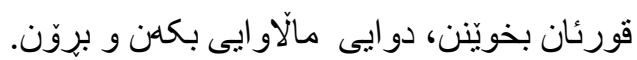

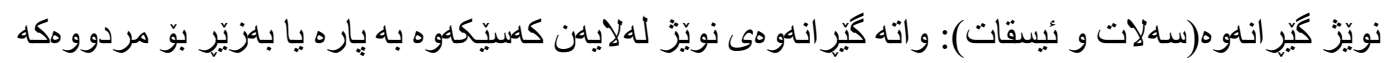

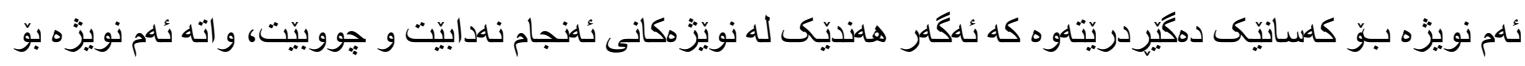

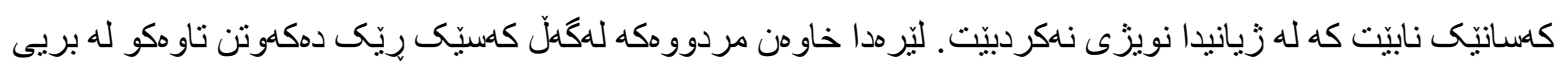

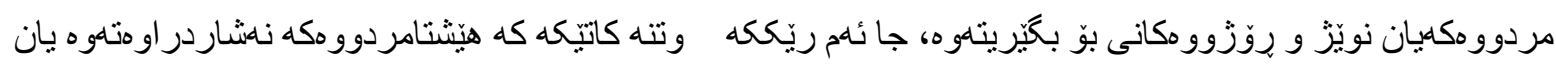

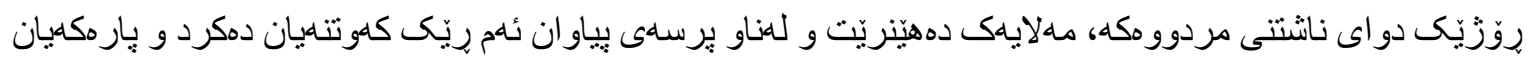

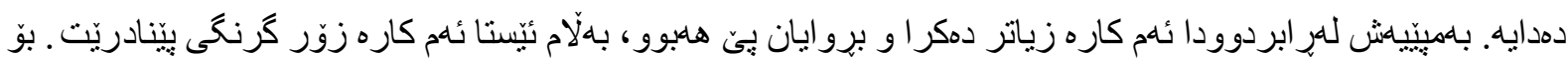

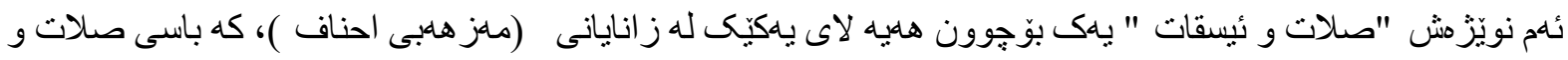




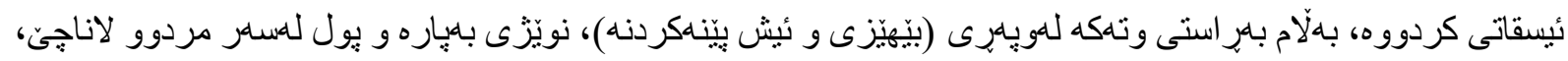

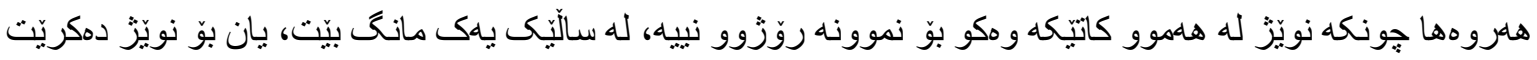

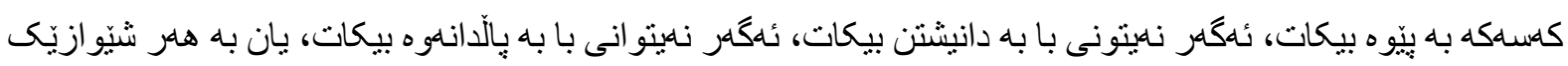

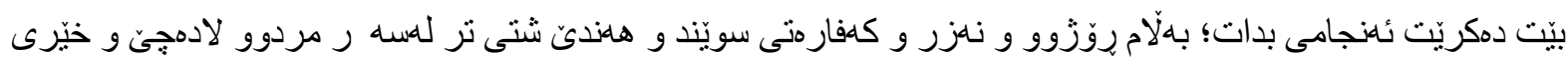

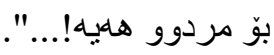

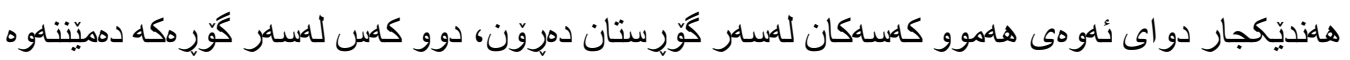

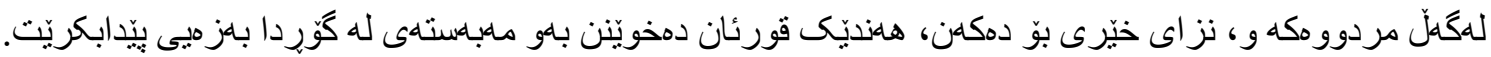

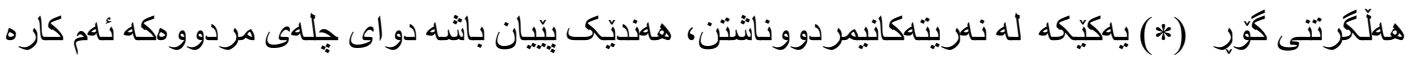

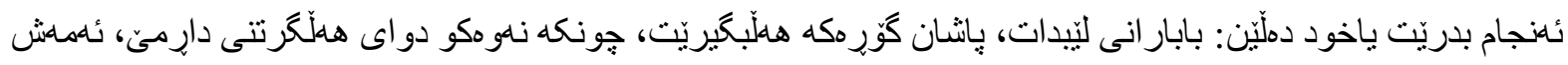
بامهبهستى ناسينهوه و بزر نهبوونى قهبر هكه دمكريّ، بهلّام له ئبسلامدا واجب نييه؛ ئهوهى دهكريّت هلندي جار زياده

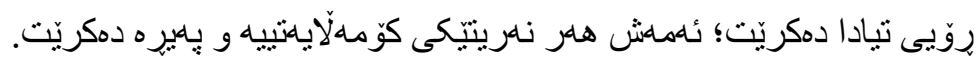

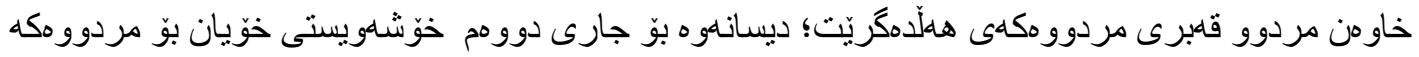

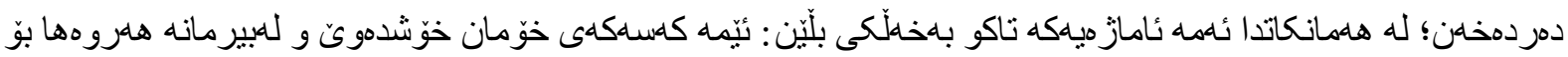

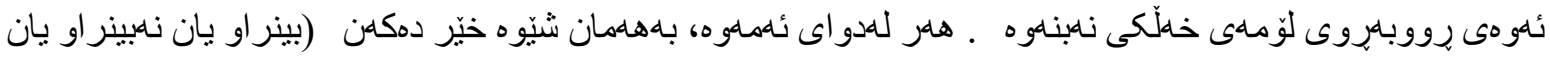

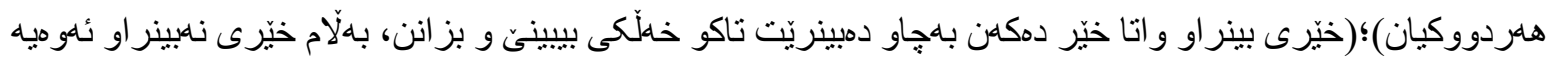

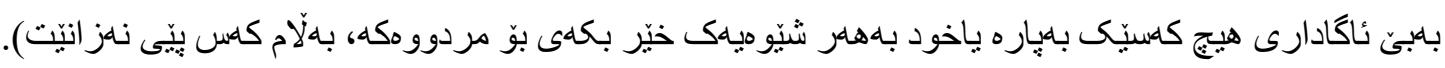

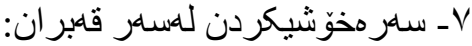

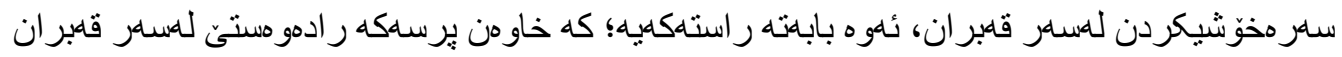

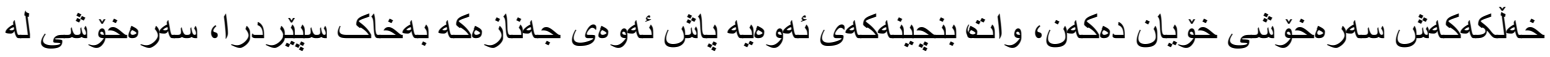

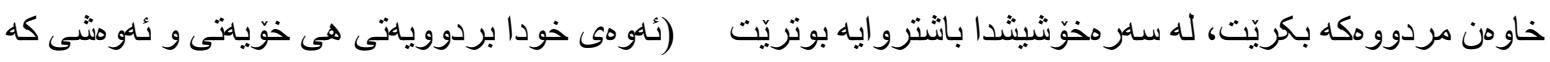

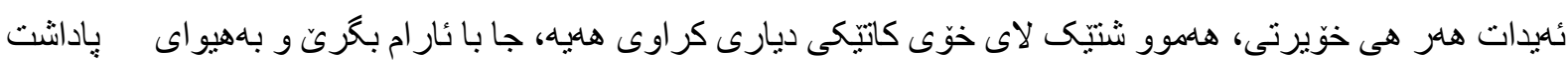

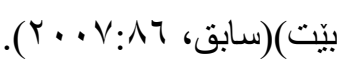

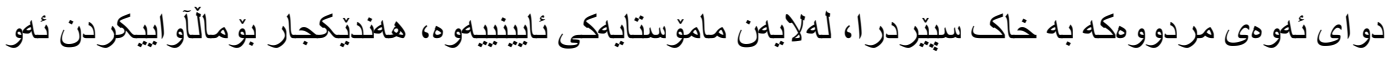

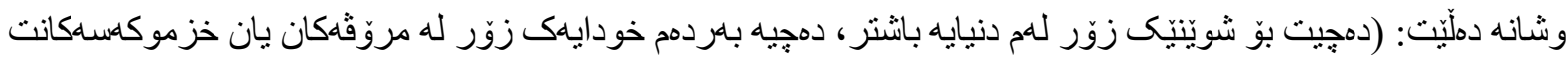

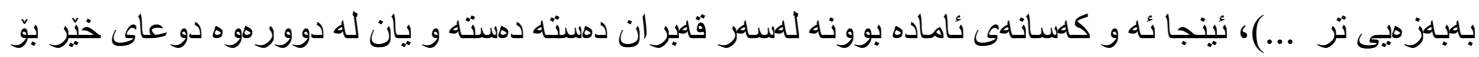

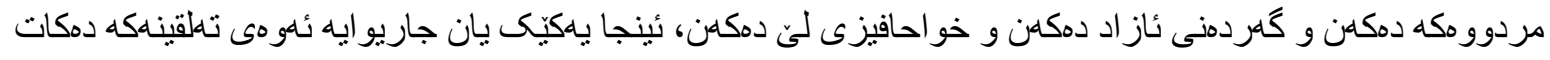

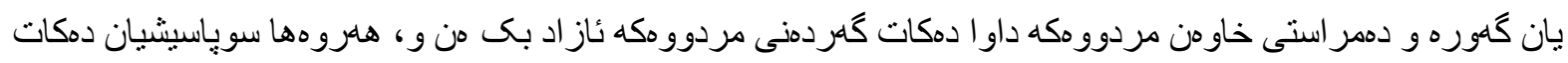

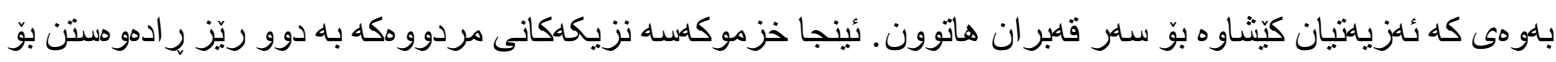

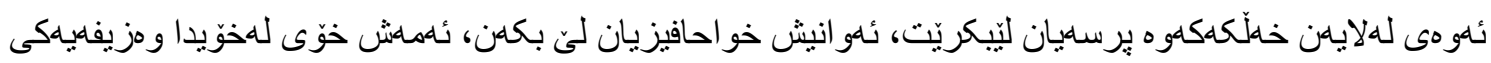

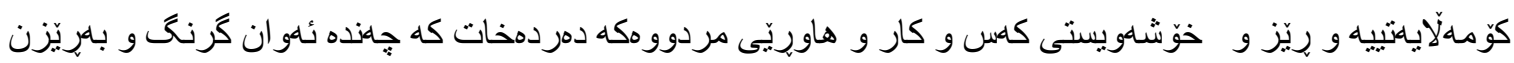

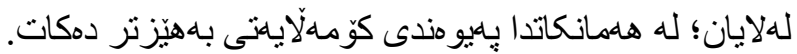

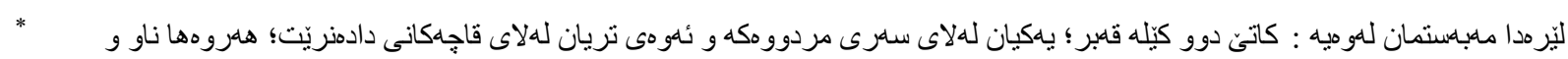

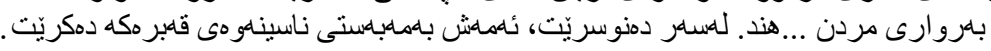




$$
\text { 1- سامر مخوّشيكردن له خاوهن مردوو: }
$$

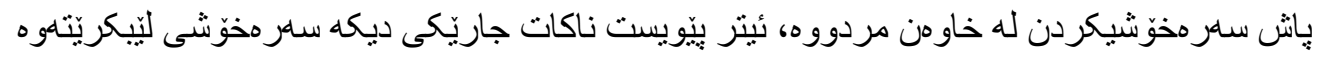

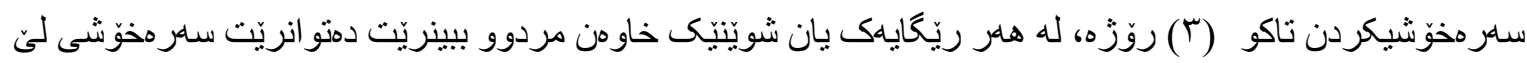

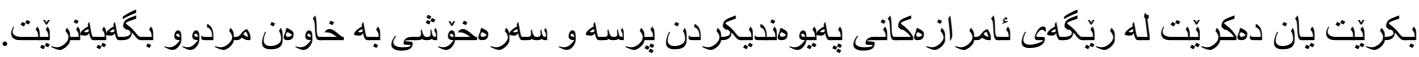

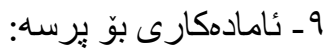

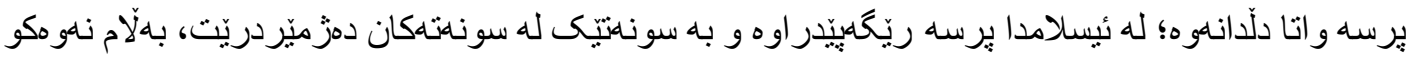

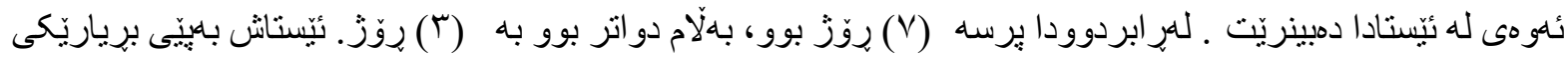

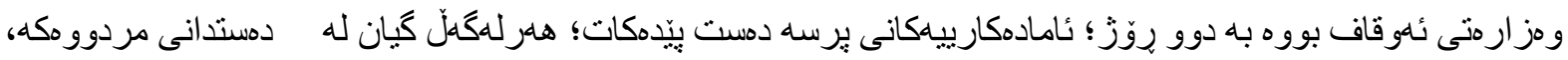

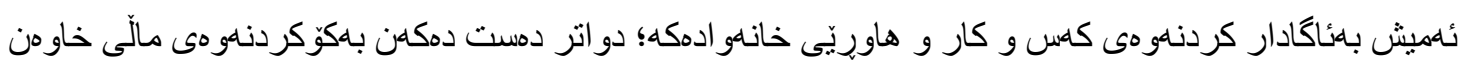

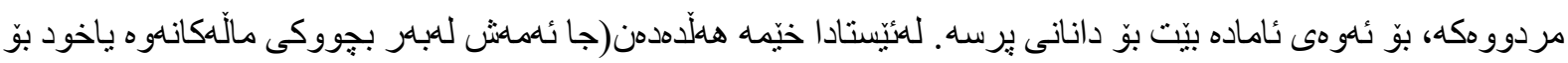

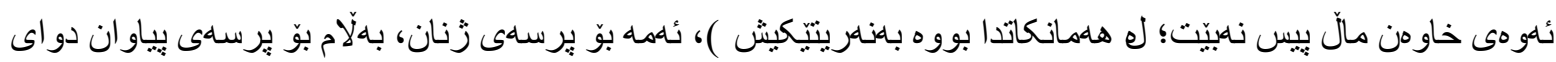

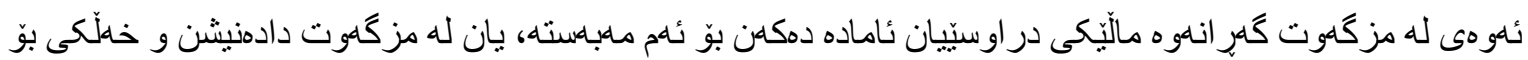

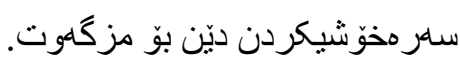

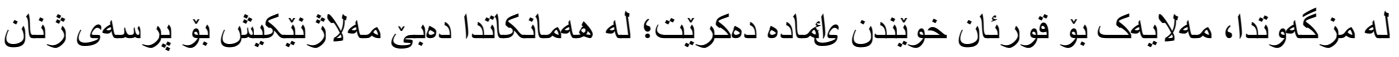

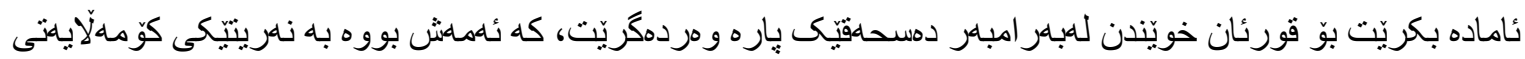

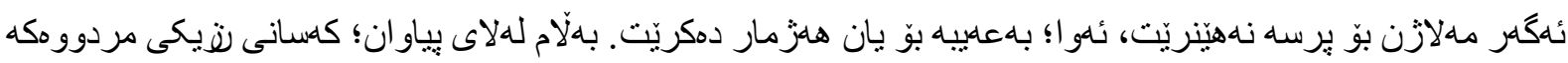

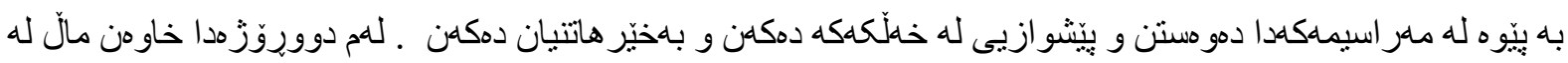

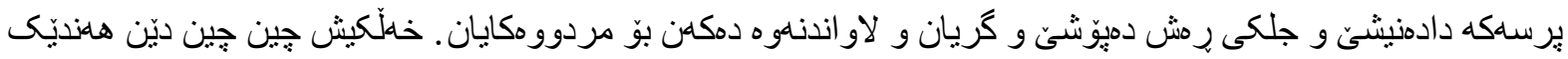

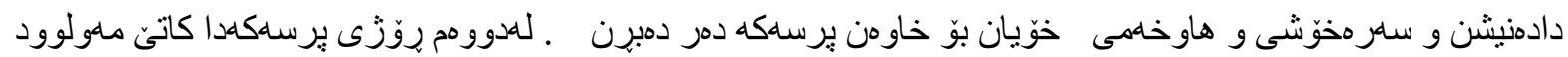

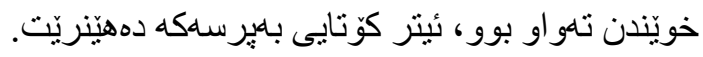

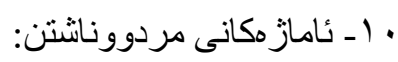

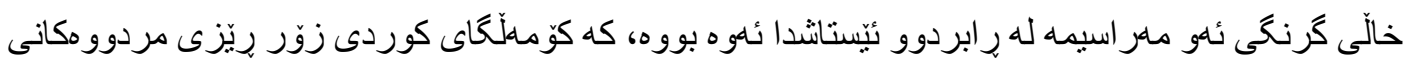

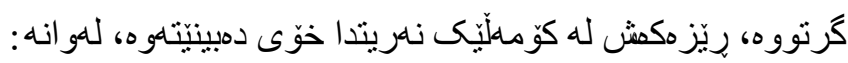

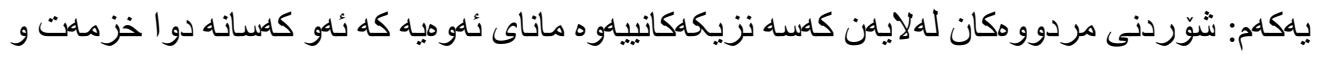

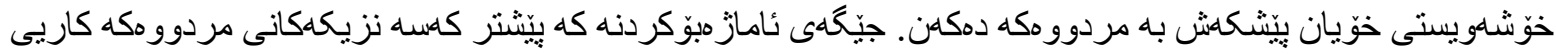

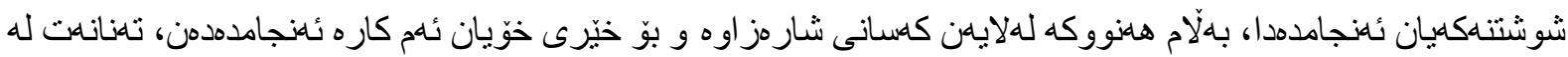

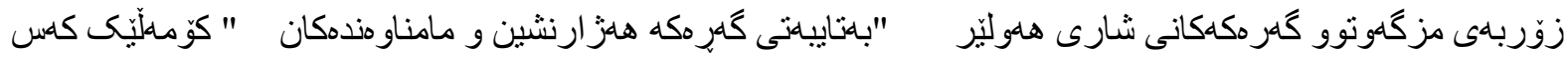

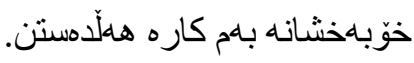

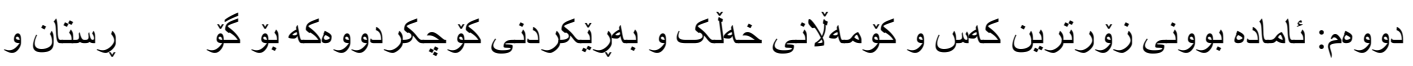

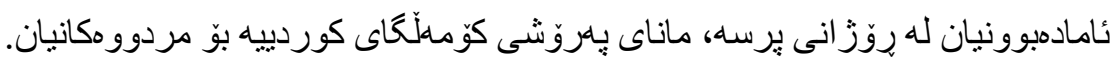




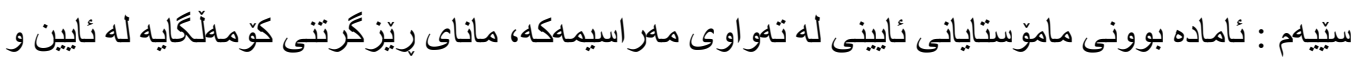

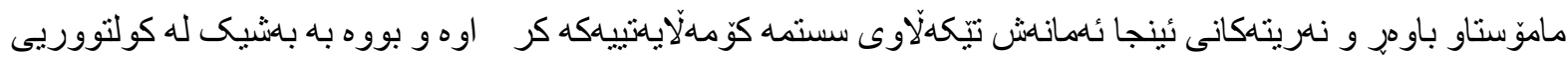

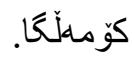

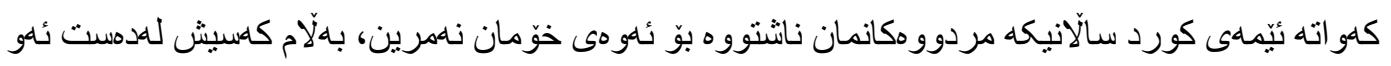

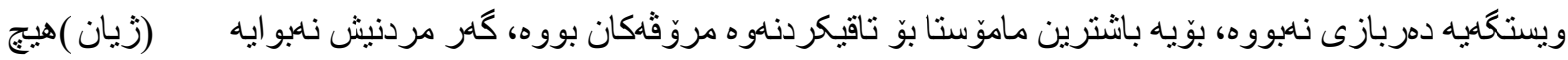

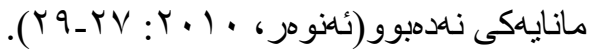

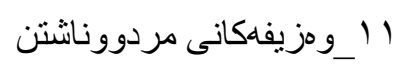

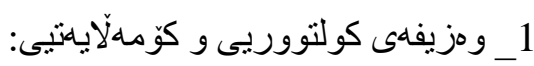

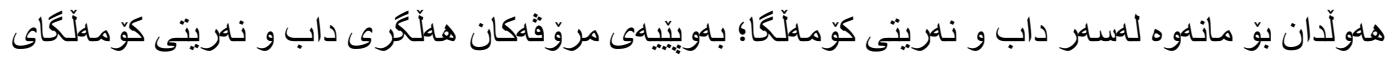

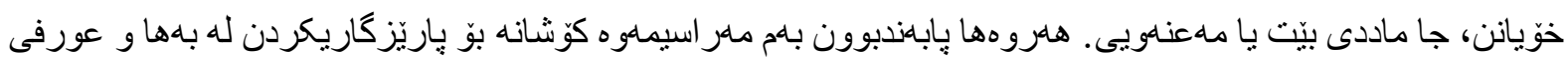

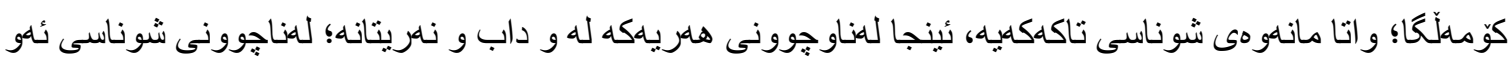

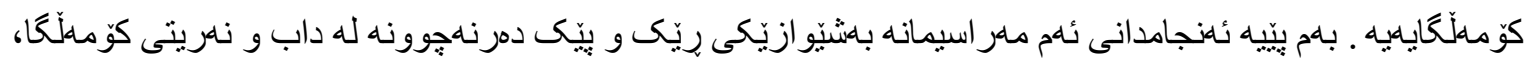

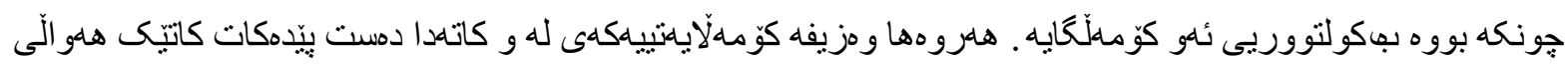

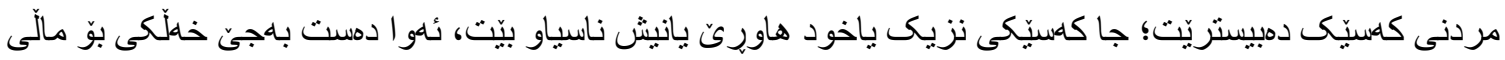

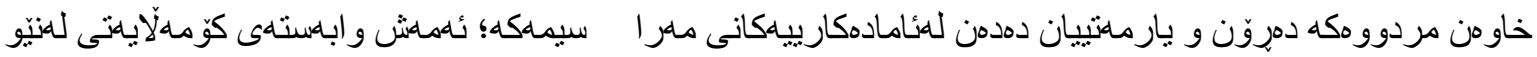

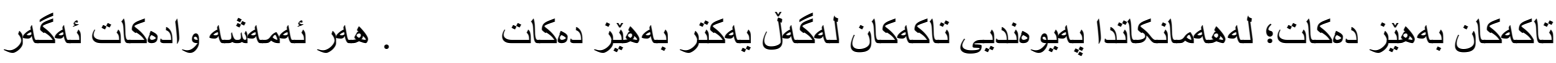

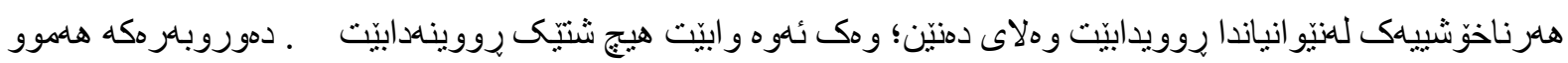

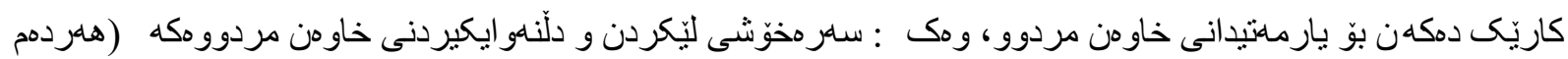

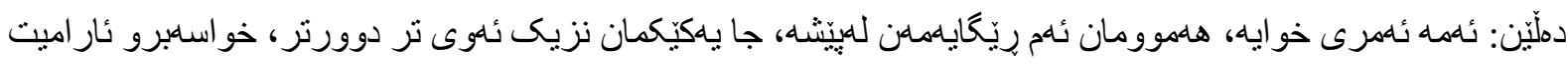

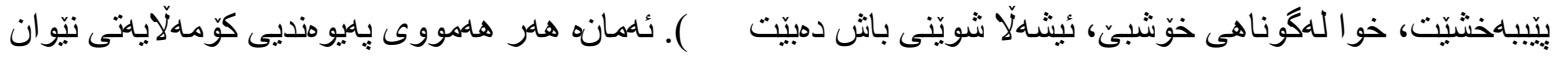

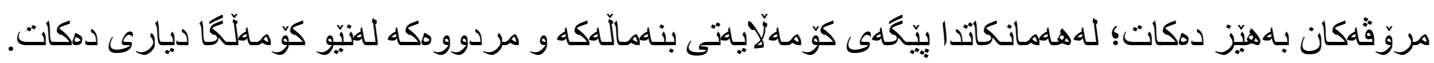

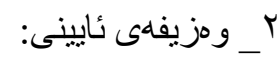

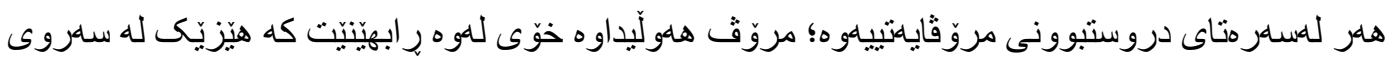

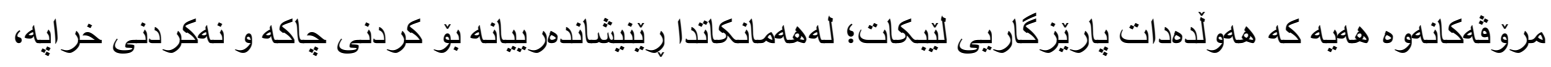

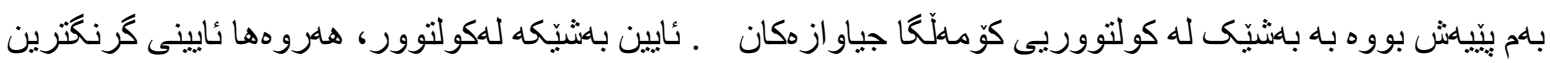

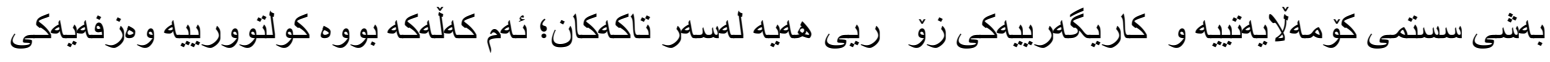

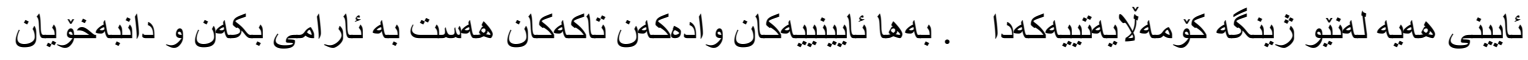

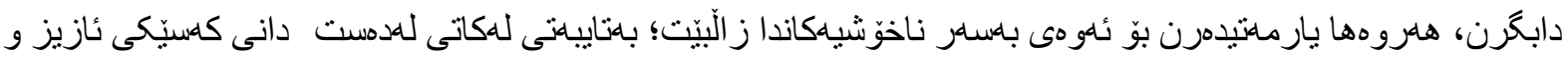

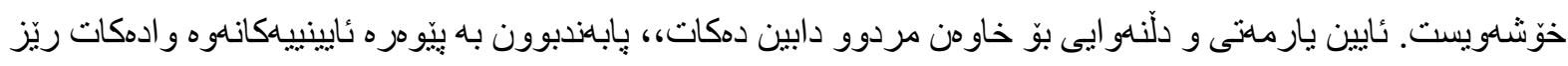

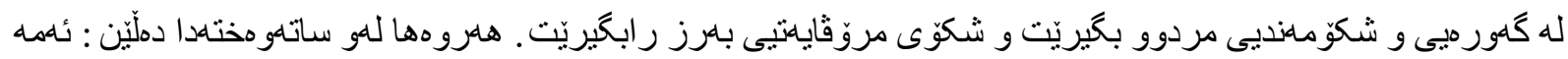

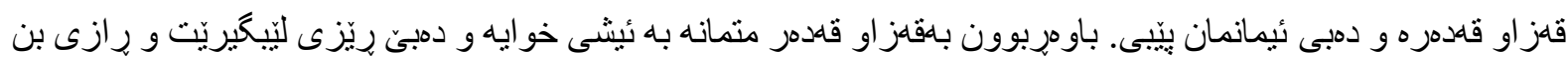

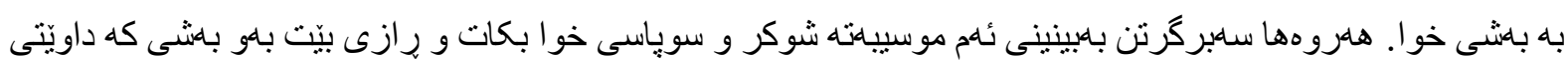

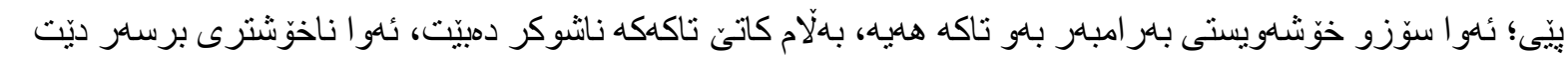




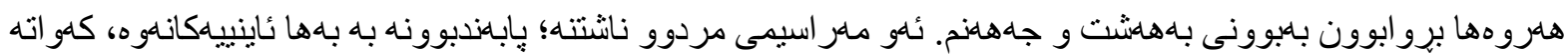

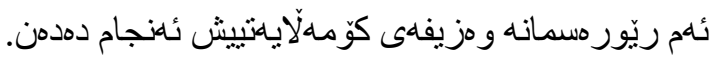

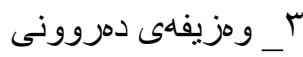

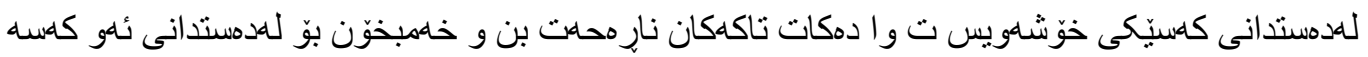

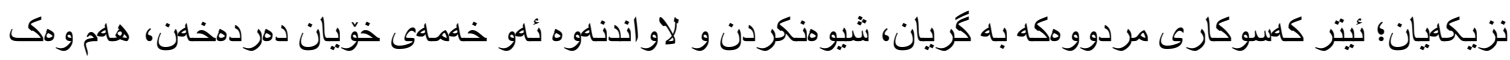

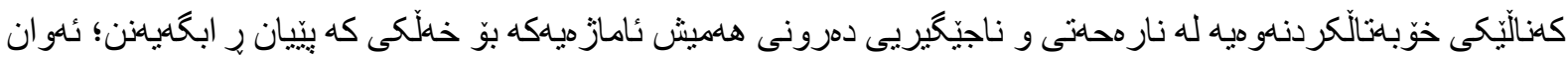
جهنده كساكهى خوّيان خوّش ويستووه.

\section{يازدهم:ئنجنجامهكانى تويّزينهوه}

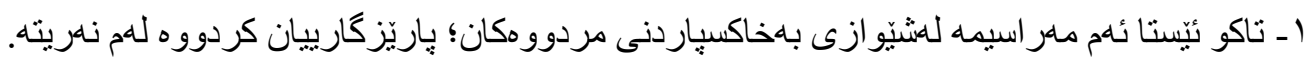

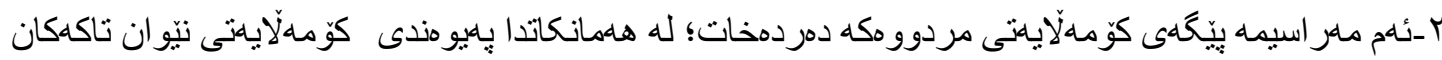

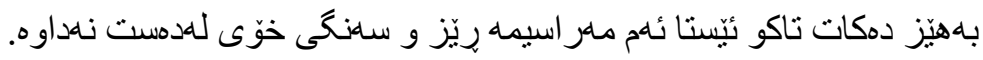

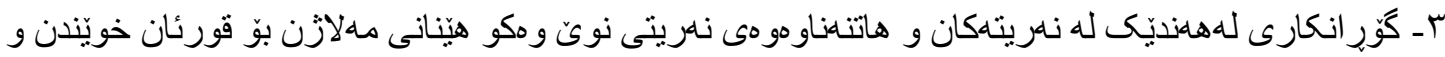

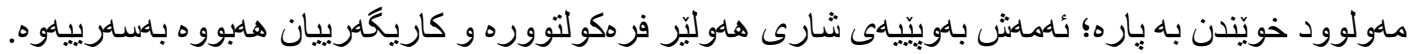

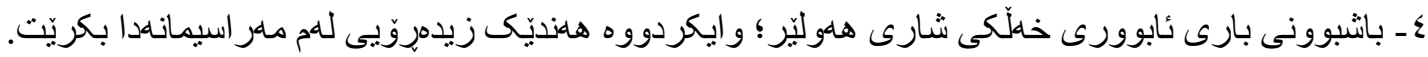

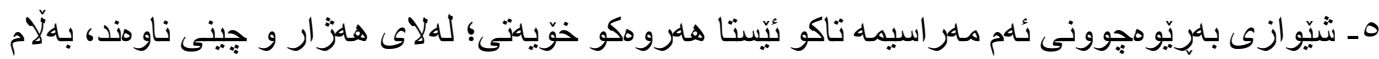

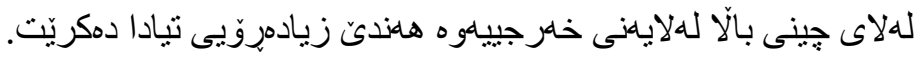

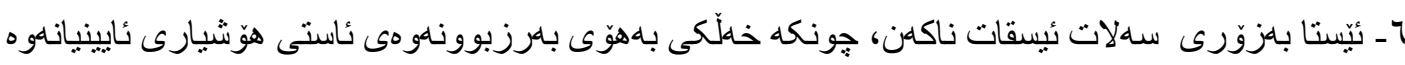

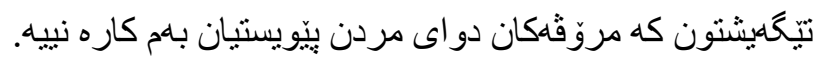

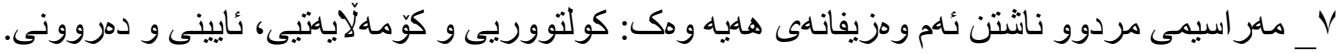

$$
\text { دو ازدهم: راسيار دمكانى تويَّزينهوه }
$$

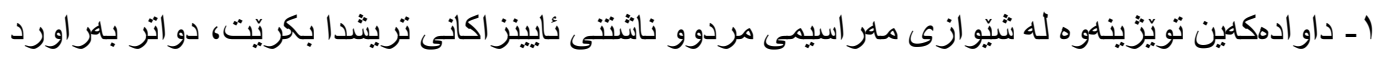

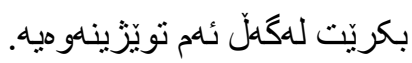

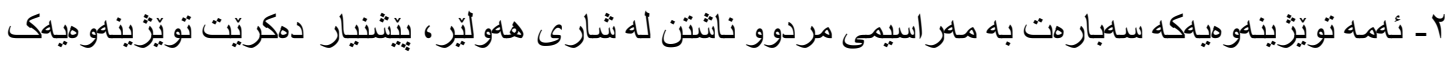

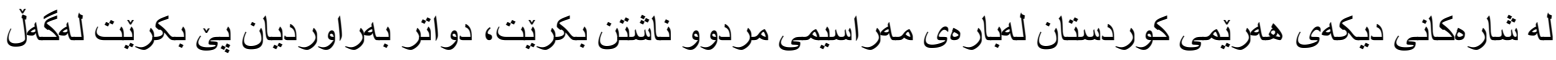

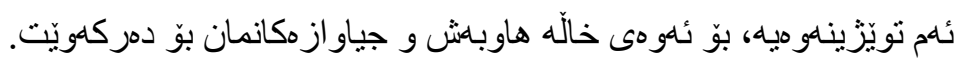

\section{سيّزدهم: بِيَشنيارهكانى تويَّينهوه}

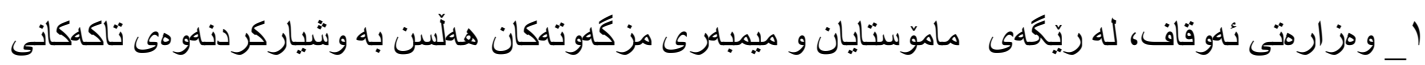

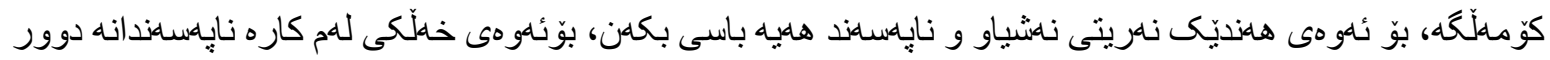
بكهويَتنهوه.

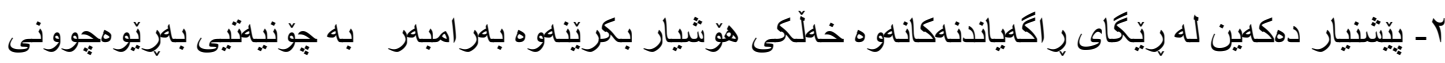

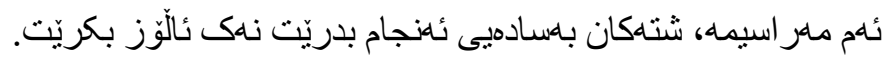




\section{References}

Abeidat, Muhemad \& Mebizin, Muhemad.(1999). The Research Methods, Oman: Waal for publication.

Abrash, Ibrahim Xelil. (2009). Scientific Method in Social Since, Ramella: Shruq forpublication.

Ahmed, Busahe. (2014). Dead in Religions, translate to Kurdish: Dana Mela Heseen, Sulemani: Andeshe for publication.

Al-Aqibw, Hnd.(2007). The Social Meaning of Dead Phenomena (Anthropological Fild Study), Dimashq Universty Journal, No.2.

Al-Hasaan, Ihsan Muhemad.(1999). Sociology Encyclopedia, Beirut: Arabic for publication.

Al-Qesas, Mehdi Muhemad.(2009). Social Research Design, Diwaniia: Nybor for publication.

Al-Sirfy, Muhemad Abdulfetah.(2008). Scientific Research (Guide Line), Oman: Waal for publication.

Al-Waali, Abduljebar.(1982). The Mind, Self and Soul, Beirut: Obeidat for publication.

Al-Xeyat, Majid Muhemad.(2010). The Basic of quantitative and qualitative research in social science, Oman: Al_raya for Publications.

Al-Xrfy : Muhemad Abdul fetah.(2008).

Al-Zebary, Tahr Hasso. (2011). The Research Methods in Sociology, Beirut: Majd Publications Organization.

Anwer, Keiwan Azad. (2010). Kurdish Tradition, Sulemani: Chwar Chra for publication.

Bayezid, Mela Mehmud.(2015). Traditons and Kurdish Documentes, translate to Kurdish: Shukrie Resull Ibrahim, Erbil: Jemil Rozhbeyani Historical center.

Hesse-Biber, S. N. \& Leavy, P. (2011). The practice of qualitative research. Translate to Arabic: Henaa Al_Jawhery. Qairo: Book Organization.

Kuban, Jan. (2007). Athnology Fild Survey, Translate to Arabic: Jehide Lawnd, Bagdad: Strategy Study Institution.

Muhsni, Manojeher. (2007). Sociology, translate to Kurdish: Muslih Ierwani, Erbil: Mukrayn Organizetion for publication.

Nashmyaz, Chava Frankort, David. (2004). The Research Methods in Social Science, Translate to Arabic: Laila Al-Teuil. Dimeshq: Btra for publication.

Qendeliji, Amr \& Al-Samaraii, Iman. (2009). Scientific Research "quantitative and qualitative”, Oman: Yazwrifor publication.

Sabr, Herdy.(2013).Etiquette for Dead with Picture. Silaimany: Sharstan for publication. 
Said, Sadq. (2007). Fiqh Sune, translate to Kurdish: Hema Amin Ahmed Berznjy. Sulaimany:

Roshnbir for publications.

Skot, Jon \& Marshall, Gordon. (2011). Sociology Encyclopedia, Translate to Arabic: Muhemad AlJawhery and The others. Qairo: Al_qewmi for translation.

Salim, Shakr Mustafa. (1981). Anthropological Dictionary, Kuet: Kuet University.

Sndi, Bedrxan. (2008). Kurdish Society in Orientalist attitudes, translate to Kurdish: Ismail Ibrahim Seid. Erbil: Mukrayn Organization for publication. 